\title{
Microscale and Mesoscale Aeolian Processes of Sandy Coastal Foredunes from Background to Extreme Conditions
}

\author{
Bianca R. Charbonneau ${ }^{1,2, *}$ and Stephanie M. Dohner ${ }^{3,4}$ (D) \\ 1 Department of Biology, University of Pennsylvania, Philadelphia, PA 19104, USA \\ 2 US Department of Defense Army Engineer Research and Development Center, Oak Ridge Institute of Science \\ and Education, Oak Ridge, TN 37830, USA \\ 3 National Research Council, Research Associate Program, Ocean Sciences Division, US Naval Research \\ Laboratory, Stennis Space Center, MS 39529, USA; stephanie.dohner.ctr@nrlssc.navy.mil \\ 4 College of Earth, Ocean, and Environment, University of Delaware, Lewes, DE 19958, USA \\ * Correspondence: bcharbon@sas.upenn.edu
}

Citation: Charbonneau, B.R.; Dohner, S.M. Microscale and Mesoscale Aeolian Processes of Sandy Coastal Foredunes from Background to Extreme Conditions. Remote Sens. 2021, 13, 4488. https://doi.org/ $10.3390 / \mathrm{rs} 13214488$

Academic Editor: Scot Smith

Received: 21 September 2021 Accepted: 2 November 2021 Published: 8 November 2021

Publisher's Note: MDPI stays neutral with regard to jurisdictional claims in published maps and institutional affiliations.

Copyright: (c) 2021 by the authors. Licensee MDPI, Basel, Switzerland. This article is an open access article distributed under the terms and conditions of the Creative Commons Attribution (CC BY) license (https:// creativecommons.org/licenses/by/ $4.0 /)$.

\begin{abstract}
Aeolian transport affects beach and foredune pre-storm morphologies, which directly contribute to storm responses. However, significant spatiotemporal variation exists within beachdune systems regarding how biotic and abiotic factors affect topography. There are multiple metrics for quantifying topographic change, with varying pros and cons, but understanding how a system changes across spatiotemporal scales relative to varying forcings is necessary to accurately model and more effectively manage these systems. Beach and foredune micro- and mesoscale elevation changes $(\Delta z)$ were quantified remotely and in situ across a mid-Atlantic coastal system. The microscale field collections consisted of 27 repeat measurements of 73 elevation pins located in vegetated, transitional, and unvegetated foredune microhabitats over three years (2015 to 2018) during seasonal, event-based, and background wind-condition collections. Unoccupied aerial System (UAS) surveys were collected to link microscale point $\Delta z$ to mesoscale topographic change. Microscale measurements highlight how $\Delta z$ varies more pre- to post-event than seasonally or monthly, but regardless of collection type (i.e., seasonal, monthly, or event-based), there was lower $\Delta z$ in the vegetated areas than in the associated unvegetated and partially vegetated microhabitats. Despite lower $\Delta z$ values per pin measurement, over the study duration, vegetated pins had a net elevation increase of $\approx 20 \mathrm{~cm}$, whereas transitional and unvegetated microhabitats had much lower change, near-zero net gain. These results support vegetated microhabitats being more stable and having better sediment retention than unvegetated and transitional areas. Comparatively, mesoscale UAS surfaces typically overestimated $\Delta z$, such that variation stemming from vegetation across microhabitats was obscured. However, these data highlight larger mesoscale habitat impacts that cannot be determined from point measurements regarding volumetric change and feature mapping. Changes in features, such as beach access paths, that are associated with increased dynamism are quantifiable using mesoscale remote sensing methods rather than microscale methods. Regardless of the metric, maintaining baseline data is critical for assessing what is captured and missed across spatiotemporal scales and is necessary for understanding the contributors to heterogeneous topographic change in sandy coastal foredunes.
\end{abstract}

Keywords: beach access path; coastal management; erosion and accretion; plant presence/absence; structure from motion (SfM); tropical and extra-tropical cyclones; UAS; vegetation stabilization; wind climatology

\section{Introduction}

Coastal foredunes are inherently dynamic interface habitats that are increasingly vulnerable to change. Rising sea levels and the increasing frequency, severity, and unpredictability of storms associated with climate change directly threaten these habitats and indirectly threaten those they protect as land-sea buffers [1,2]. Foredunes, defined as the first backshore, shore-parallel, vegetated dune ridge formed by aeolian sand deposition [3], 
are the first line of defense for inland features and infrastructure during high tides and storms. Despite their geological instability, these areas support increasing population sizes, infrastructure development, recreational activities, and economic investment [4-7]. Storm surge flooding and dune collision erosion [8] remain the main focus of assessing storm-induced changes [9-14]. However, wind events can significantly alter dune topography [14-17] and are predicted to contribute to increased erosion events in the future [18].

Aeolian transport affects dune habitat storm impact, which is largely dependent on the height of a foredune relative to storm surge [19-21]. Pre-storm dune elevation, volume, and shape are sensitive to both aeolian input and wave dissipation rates [22]. Storms may cause dune collision erosion and overwash, but between storm events, wind transport ultimately shapes topography to its next pre-storm state $[8,14,16,17,19]$. More powerful wind events garner the most research attention $[13,23]$, in part because they tend to be associated with collision erosion and inundation, although they may also co-occur with rain, thereby limiting transport [24-26]. Significant aeolian transport from the beach to dunes is associated with low- to medium-magnitude wind events [26], with both wind speed and direction ultimately impacting transport $[17,27,28]$.

Topography and obstructions (e.g., plants, structures) steer near-surface winds, altering transport. Wind velocity typically slows at the toe, accelerates upslope, then decreases at the crest and leeward slope [29-31]. Within the dune, transport decreases inland [32], and features like paths can funnel winds creating conditions for accelerated erosion [11]. Aboveground biomass can capture sediment and increase deposition even at 1\% cover [33-37], affecting both wind and wave transport $[23,38]$. Foredune volume and vegetation cover are positively related [39], but more vegetation does not necessarily trap more sand [35,37,40]. In blowout and washover fans lacking vegetation [41-44], point measurements of aeolian transport and elevation change have been made [29,42-45]. However, across the broader beach-dune system, reported changes are more typically volumetric and measured via remote sensing $[13,14,26]$, but variable sediment erosion and accretion across a system drive topographic heterogeneity [24,25].

Wind direction and intensity can vary seasonally, altering sediment transport between and among events. For example, in the Mid-Atlantic US, northeasterly winds predominate September to October, with hurricane season being from 1 June to 30 November [46]. Wind velocity also tends to be most seasonally mild in the Pacific Northwest US in the summer months [47]. As a result, milder elevation changes may be expected over summers such as in a Mediterranean and US dune system where elevation pins across a growing season showed $<6 \mathrm{~cm}$ and $<10 \mathrm{~cm}$ net accumulation April to September, respectively [48,49]. Annual net erosion or deposition may also be mild (less than $10 \mathrm{~cm}$ ) as exemplified by the lacustrine dunes of Michigan, USA, from 1990 to 1998, where foredunes experienced a net deposition of 1-6 cm [50]. However, dune elevation is rarely stable, as one event can alter topography drastically, inducing 58 to $90 \mathrm{~cm}$ elevation gains in a year [12,13,38,51], with drastic localized changes in microhabitats [49]. Varying sediment transport ultimately impacts plant emergence and zonation as additional drivers of topographic heterogeneity [52].

Several approaches exist to remotely monitor the coastal beach system such as satellite orthoimagery, airborne lidar, unoccupied aerial vehicles (UAS), terrestrial laser scanners, stationary cameras, radar, ground-penetrating radar, and more [14,53-55]. Each has positive and negative aspects regarding the accuracy and ability to also quantify or compare to ecological data. When to use a particular method or combination of methods typically depends upon the size of the site, frequency of observations required, and spatial resolution of the resulting data [14]. Additional factors for choosing a remote sensing method include cost of the platform, sensors, processing software, and training. Perhaps an underrepresented factor includes the consideration and inclusion of stakeholders and end-users of these datatypes, who need to be considering when choosing a platform, sensors, and data type to encourage the use of the information as well as sustainability of the method or dataset by management, conservation, and monitoring groups. 
Understanding how dune systems change across different spatiotemporal scales relative to biotic and abiotic aeolian forcings is necessary to more accurately model future scenarios and better manage these systems $[5,56,57]$. Towards this goal, beach and foredune elevation changes were quantified across a Mid-Atlantic coastal system from 2015 to 2018 as seasonal, event-based, and background wind conditions. Remote sensing UAS surveys and more frequent field point measurements within vegetated, transition, and unvegetated barren foredune microhabitats were made. Mesoscale habitat level change is assessed relative to targeted change at localized points with associated physical and biological attributes ascribed. The point measurements are straightforward to collect and maintain, as remote sensing measurements are more computationally expensive [14], but both change metrics are options for coastal practitioners in assessing landscape states.

\section{Materials and Methods}

\subsection{Study Site}

Island Beach State Park (IBSP), is a high barrier island [58] located along the Barnegat Bay Peninsula, Berkeley Township, and Ocean County, NJ, USA (Figure 1). It is a microtidal environment containing $\approx 17 \mathrm{~km}$ of sandy beach shoreline transitioning the full range of barrier island habitats from littoral to dune, maritime forest, and tidal marsh. The mean grain size is medium quartz sands, $0.300-0.350 \mathrm{~mm}$. The foredunes are dominated by native Ammophila breviligulata or invasive Carex kobomugi, with minor exceptions where Toxicodendron radicans is prevalent [38]. The growing season runs from May to October and annual precipitation is $\approx 127 \mathrm{~cm}$. Precipitation and wind speeds are seasonally lowest April through August, with prevailing winds blowing from the southwest. Conversely, northerly winds and storms in the fall and winter have the greatest transport potentials $[17,29]$. Hurricane Sandy (October 2012) is the most recent major storm to impact IBSP [10]. The park recreation area is bounded by a north and south natural area $(\approx 1.5 \mathrm{~km})$ that are largely unmanaged. Between these areas is the recreational area of the park where prior to Sandy, the foredune was largely continuous, excluding the 24 beach access paths through the system. Here, Hurricane Sandy erosion was variable, increasing south to north latitudinally [38] with beach access 1 (A1) being the most northerly.

Field collections were performed among the foredunes A15-A24 $(\approx 3 \mathrm{~km})$. Here, collision erosion from Hurricane Sandy occurred, but the foredunes were not overwashed or inundated [8]. The foredunes north of A15 experienced overwash and inundation and were largely destroyed. High wind speeds from Hurricane Sandy created blowouts and exacerbated the size and depth of previously existing blowouts in the foredunes and extending into the secondary dunes [38,49]. Over five years, as much as $2 \mathrm{~m}$ of deposition was documented in blowouts at IBSP with variation within and among these features [29]. Since Hurricane Sandy, the system had been recovering with minimal disturbances until fall 2016, when Hurricane Joaquin caused collision erosion and high winds [13].

\subsection{Microscale Metrics: Elevation Pins}

A total of 73 elevation pins (i.e., erosion pins $[29,43,44]$ ) were installed in three foredune microhabitats and their heights, relative to the surface, were monitored from 2015 to 2018 (Figure 2). The pin microhabitats vary within the foredune (blowout center, blowout periphery, or foredune center) and vegetation cover (unvegetated, transitional, or vegetated). Transitional pins being at blowout peripheries were half vegetated, one side was barren, and the other vegetated. All pins were sturdy (fiberglass or steel), driven $\geq 15 \mathrm{~cm}$ into the sand, and GPS-marked. Data consists of repeat measures of pin height over time (sediment surface to pin top), to examine elevation change ( $\Delta z)$ between successive measurement times referend to as collections. Negative and positive $\Delta z$ values indicate erosion and accretion, respectively and $\Delta z$ could only be determined for pins present in both collection $T_{x}$ and $T_{x+1}$; the sample sizes presented in Table 1 reflect instances of $\Delta z$ not being possible to compute between collections. During collections, if a pin was missing, then its location was dug to ensure it was not buried; if buried, then burial depth relative 
to surface height was recorded and a new pin was installed. A new pin was also installed for any missing pins, and for any pins within $0.3 \mathrm{~m}$ of being buried.

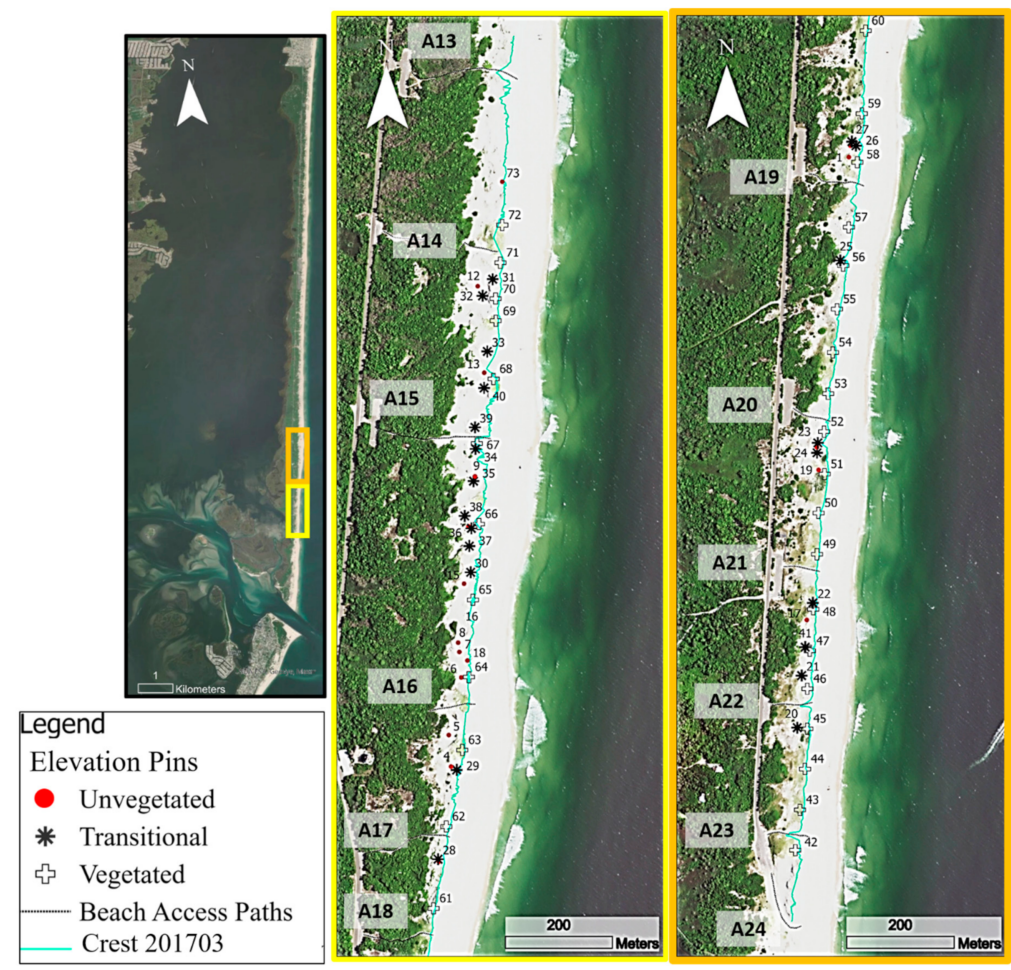

Figure 1. Island Beach State Park, NJ collection area. Data collection consisted of quantifying changing elevation at point locations in three foredune microhabitats: in blowouts (unvegetated), at $75 \mathrm{~m}$ and $150 \mathrm{~m}$ spacing along the foredune in its center (vegetated), and at the periphery of blowout edges, half vegetated and half barren (transitional). The background satellite imagery is USDA NAIP $1 \mathrm{~m}$ orthoimage from June 2015.

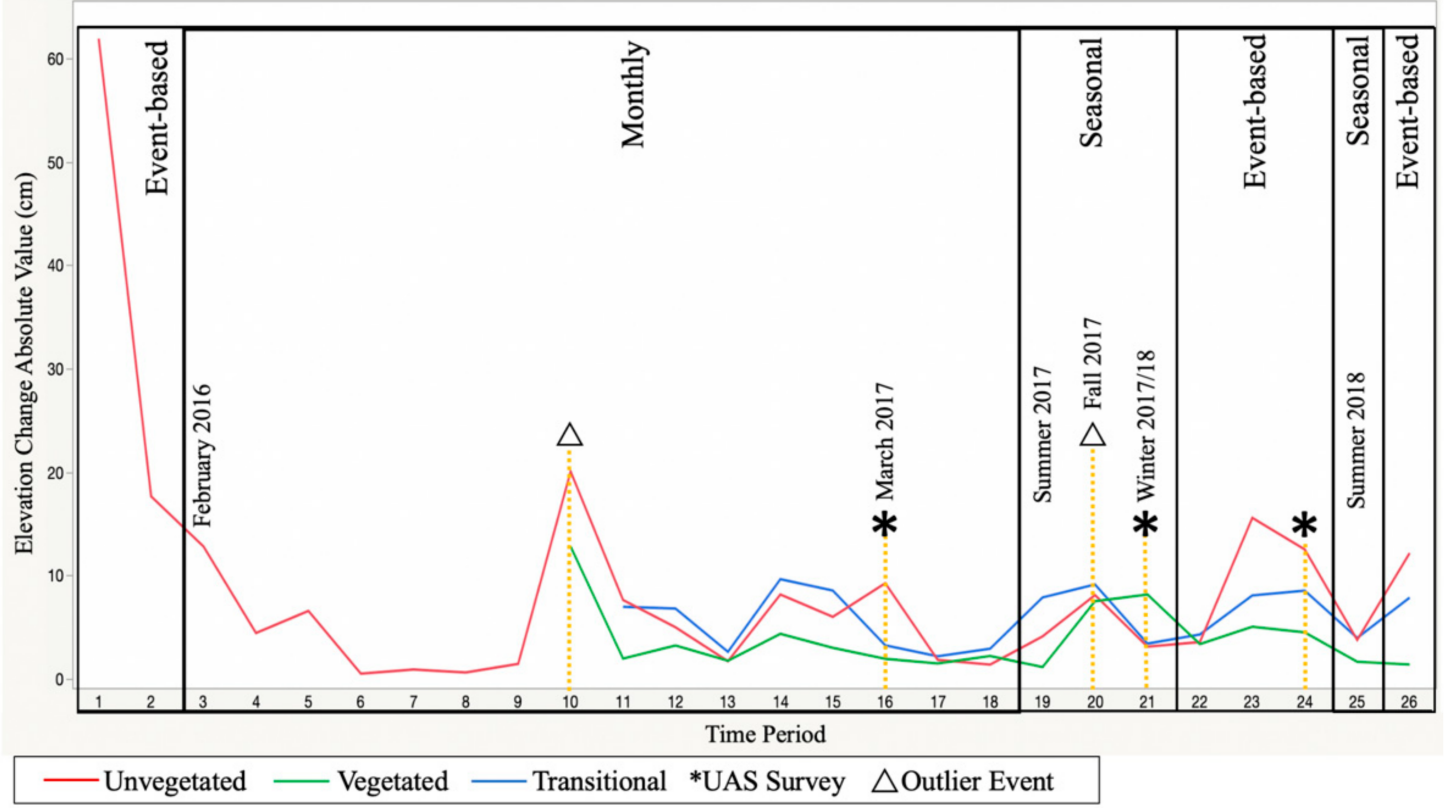

Figure 2. Microscale elevation pin collections were event-based, monthly, or seasonal from June 2015 to September 2018. Associated UAS flights were largely seasonal. 
Table 1. Dates of all 27 total collections for the elevation pin types installed throughout the IBSP foredunes. The number in each cell represents the sample size of each period reflecting pins going missing or becoming buried between collections. Blue cells denote the period number, $\Delta z$ from one collection to the next, where period one is $\Delta z$ between collections one and two.

\begin{tabular}{|c|c|c|c|c|c|c|c|c|c|c|c|c|c|c|c|c|c|c|c|c|c|c|c|c|c|c|c|}
\hline Date & 号 & $\begin{array}{l}10 \\
\stackrel{1}{1} \\
0 \\
o \\
o\end{array}$ & 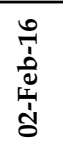 & 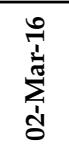 & 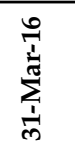 & 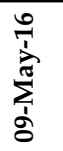 & $\begin{array}{l}\stackrel{0}{1} \\
\stackrel{1}{5} \\
\frac{1}{8}\end{array}$ & 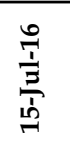 & 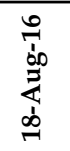 & 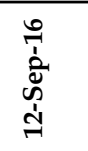 & \begin{tabular}{l}
0 \\
\multirow{1}{1}{} \\
0 \\
$\stackrel{1}{1}$ \\
\end{tabular} & 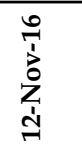 & 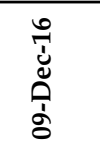 & 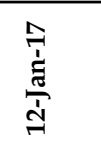 & 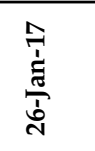 & 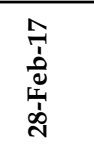 & $\frac{N}{\sum_{i}^{\pi}}$ & $\frac{\hat{a}}{\frac{1}{2}}$ & 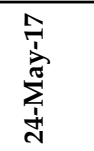 & 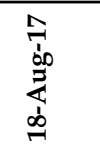 & 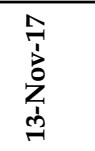 & 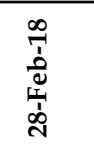 & 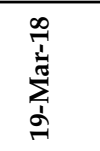 & 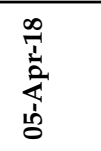 & 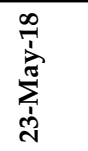 & 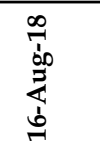 & $\begin{array}{l}\infty \\
\frac{1}{1} \\
\frac{0}{0 े} \\
\infty \\
\text { ஸे }\end{array}$ \\
\hline Collection & 1 & 2 & 3 & 4 & 5 & 6 & 7 & 8 & 9 & 10 & 11 & 12 & 13 & 14 & 15 & 16 & 17 & 18 & 19 & 20 & 21 & 22 & 23 & 24 & 25 & 26 & 27 \\
\hline Unvegetated & 12 & 8 & 10 & 10 & 11 & 10 & 12 & 12 & 12 & 12 & 16 & 18 & 17 & 17 & 17 & 18 & 17 & 16 & 16 & 16 & 17 & 17 & 17 & 17 & 18 & 18 & 16 \\
\hline Vegetated & - & - & - & - & - & - & - & - & - & 31 & 31 & 31 & 30 & 31 & 29 & 29 & 30 & 31 & 31 & 28 & 27 & 28 & 29 & 31 & 31 & 31 & 30 \\
\hline Transitional & - & - & - & - & - & - & - & - & - & - & 20 & 21 & 21 & 22 & 22 & 22 & 22 & 21 & 19 & 22 & 21 & 22 & 22 & 19 & 19 & 20 & 19 \\
\hline Period & 1 & $1 \& 2$ & $2 \& 3$ & $3 \& 4$ & $4 \& 5$ & $5 \& 6$ & $6 \& 7$ & $7 \& 8$ & $8 \& 9$ & $9 \& 10$ & $10 \& 1$ & $11 \& 1$ & $12 \& 13$ & $13 \& 14$ & $14 \& 15$ & $15 \& 16$ & $16 \& 17$ & $17 \& 18$ & $18 \& 19$ & $19 \& 20$ & $20 \& 21$ & $21 \& 22$ & $22 \& 23$ & $23 \& 24$ & $24 \& 25$ & $25 \& 26$ & 26 \\
\hline
\end{tabular}


An initial 20 pins were installed on 10 June 2015, in the blowout centers (unvegetated, installed in the flat center). These were $1.37 \mathrm{~cm}$ diameter galvanized steel, placed at $1 \mathrm{~m}$ height above the surface. Initially, collections were event-driven, as a proof-of-concept, then were monthly for 16 months (February 2016 to June 2017, collection 3 to 19), then seasonally (beginning and end of a season) and event-based until the final collection in the fall of 2018 (Table 1 and Figures 1 and 2). Event-based collection dates were opportunistic and based upon weather predictions pre-storm, reports of measured wind velocities post-storm, or post-event wind and wave data from NOAA Tides and Currents, the National Center for Environmental Prediction, and the National Hurricane Center (NHC). Over the study duration, there were 27 total collections for the unvegetated pins.

After collection nine, 53 additional pins were installed in different microhabitats for comparison due to NHC hurricane forecasts. On 18 August 2016, collection 10, an additional 31 pins were installed in the foredune vegetation, $8 \mathrm{~m}$ from the crest, between the crest and secondary dune (i.e., foredune heel), and in the foredune crest, as mapped by Charbonneau et al. [38]. Pins' install locations were pre-defined in ESRI ArcMap v10.8.1 at uniform distances, latitudinally, every $75 \mathrm{~m}$ from the southern study extent for $1.5 \mathrm{~km}$, and then every $150 \mathrm{~m}$ thereon, northward (Figure 1). All vegetated pins were at least $25 \mathrm{~m}$ from the closest beach access path and the vegetation stands they were installed in were dominated by either invasive C. kobomugi $(n=14)$ or native A. breviligulata $(n=17)$. On collection 11, a final 22 pins were installed at the peripheral edge (east wall $n=20$ ) of blowouts, representing the transition between the vegetated foredune and the unvegetated blowout. These were the only pins installed on a slope and the 22 stands were all dominated by $A$. breviligulata largely as pure monocultures except for one stand dominated by C. kobomugi and the occasional presence of a handful of secondary stabilizing species such as Seaside Goldenrod (Solidago sempervirens) or Sea Rocket (Cakile endulata; [49]). The full range of species found at each transect over time can be found in Charbonneau, 2019 [49]. These 53 total pins were $1.8 \mathrm{~m}$ fiberglass driveway markers driven $0.5 \mathrm{~m}$ into the ground. All replacement pins were of this making. Pictures of pins are available in Supplemental 1.

\subsection{Mesoscale Remote Sensing Data Collection}

Three UAS surveys were performed at $80 \mathrm{~m}$ altitude, and $80 \%$ and $75 \%$ along and across track overlap, respectively, with a DJI@ Phantom 3 Advanced with standard camera payload or SenseFly eBee@ RTK with SenseFly DSC-WX220 camera. Geotagged images were mosaicked using SfM software (Pix4D@, Agisoft $\odot$ Photoscan, now Metashape) across the full collection area encompassing the foredune, beach, and swash zone [14]. UAS survey dates were 3 March 2017 (flight 1, DJI Phantom 3 Advanced) as plants broke dormancy ahead of a potential storm, December 11, 2017 (flight 2, SenseFly eBee RTK) after the end of the 2017 hurricane season, and April 22, 2018 (flight 3, SenseFly eBee RTK) following the winter storm season (Figure 2). Flights coincided with a pin survey. All flights were referenced with ground control points, every $\approx 100 \mathrm{~m}$ along the study extent, which were permanent road fixtures west of the foredune and temporary beach markers surveyed with a Topcon@ GR-5 RTK GPS system [14]. Survey platform resolution and uncertainties are presented in Table 2. Uncertainties were calculated from in situ objects (i.e., field vehicles, beach artworks, dumpsters, etc.). Publicly available lidar DEMs filled temporal gaps between UAS and microscale surveys (Table 2). All elevation datasets were transformed to New Jersey State plane coordinates before analyses and DEMs $(1 \mathrm{~m}$, gridded) were processed for elevation derivatives such as slope, profile curvature, and aspect using corresponding tools within ArcGIS Pro. 
Table 2. Remotely sensed data sources, platforms, dates, spatial resolutions, and uncertainties.

\begin{tabular}{|c|c|c|c|c|c|}
\hline Data & Source/Instrument & $\begin{array}{l}\text { Dates } \\
\text { (yyyy-mm-dd) }\end{array}$ & $\begin{array}{l}\text { Resolution } \\
\text { (Grid or Cell Size) }\end{array}$ & Uncertainty & Analysis \\
\hline satellite imagery & USDA NAIP & 7 June 2015 & $1 \mathrm{~m}$ & $\pm 6.1 \mathrm{~m}$ & $\begin{array}{l}\text { map background; } \\
\text { mask creation }\end{array}$ \\
\hline $\begin{array}{l}\text { topobathy lidar } \\
\text { DEM }\end{array}$ & $\begin{array}{l}\text { USGS, NOAA, } \\
\text { CMP, USACE }\end{array}$ & $\begin{array}{l}\text { 2014, September } \\
2017\end{array}$ & $1 \mathrm{~m}$ & $\pm 0.09-0.15 \mathrm{~m}$ & mesoscale metrics \\
\hline UAS DEM & $\begin{array}{l}\text { DJI }{ }^{\circledR} \text { Phantom } 3 \\
\text { Advanced }^{\mathrm{TM}}, \\
\text { eBee }^{\mathrm{TM}} \text { SenseFly }\end{array}$ & $\begin{array}{l}21 \text { March 2017, } \\
11 \text { December 2017, } \\
22 \text { April } 2018\end{array}$ & $0.05 \mathrm{~m}$ & $\pm 0.15 \mathrm{~m}$ & mesoscale metrics \\
\hline mapped features & $\begin{array}{l}\text { Trimble }^{\circledR} \text { GeoXTTM } \\
\text { GeoExplorer }{ }^{\circledR}\end{array}$ & 2013-2018 & $0.15 \mathrm{~m}$ & $\pm 0.8 \mathrm{~m}$ & microscale metrics \\
\hline sediment samples & coring, brab & 2018 & - & - & $\begin{array}{l}\text { aeolian critical } \\
\text { threshold }\end{array}$ \\
\hline
\end{tabular}

\subsection{Mesoscale Metrics Derived from Digital Elevation Models}

Feature extraction of the dune's crest location, mean higher high water (MHHW) line, beach width, crest elevation, and surface elevations, at all pins, occurred in ArcGIS Pro v2.8. The custom-created ArcGIS model extraction tools are detailed in Supplemental 2. In the tool, crest line features were identified from the maximum positive profile curvature for the subaerial beach [59], and elevations were extracted along each survey every $0.2 \mathrm{~m}$; this tool could be used to extract the dune toe modified for maximum negative curvature. NOAA tide gauge MHHW values $(z=0.61 \mathrm{~m}$; station 8534720$)$ were used to extract the MHHW location as polylines from subaerial DEMs. Beach width represents the distance between the crest and MHHW, as this area was consistently exposed to aeolian processes during non-precipitation periods. Masks of the subaerial study extents of beach and woody habitats were generated using visual satellite orthoimagery delineation (Table 2). These masks aided extraction tools by decreasing false positives when searching for desired criteria and removing woody habitats. Each extraction method entailed minor buffering and smoothing conditions to remove erroneous values.

Elevation was extracted and $\Delta z$ computed between flights at pin locations. DEMs were differenced to create a $\Delta z$ surface where each grid was also categorically defined as having experienced erosion or accretion between flights. A spatial sensitivity analysis was performed to quantify the distance pin $\Delta z$ agreed with categorical $\Delta z$ (i.e., erosion or accretion) using the Distance and Direction tool to manually draw a radius from each pin on the categorical $\Delta z$ surface to the nearest categorical switch.

Beach access-path impacts were quantified using a custom ArcGIS tool (Supplemental 3). The tool utilizes $\Delta z$ surfaces between consecutive surveys to create standard deviation surfaces, where impact polygons are defined by isolating areas greater than one standard deviation of the mean (Figure S2.1). Beach path polylines (previously mapped [38]) were buffered by $12.2 \mathrm{~m}$ and used to extract areas from the standard deviation surface. The buffer size was based on local topography to exclude nearby blowouts. Polygons larger than $0.93 \mathrm{~m}^{2}$, based on raster resolution, were analyzed using the Minimum Boundary Geometry tool to determine access the impact's major and minor axes, surface area, orientation, and perimeter. These parameters are collectively referred to as access-impact geometries. Using the $\Delta z$ surface, access impacts were categorized as erosional or accretional and polygons were manually identified as the head (inland), crest (seaward termination), or middle. Access impacts were quantified chronologically in three instances 2014 (lidar) to September 2017 (lidar), September 2017 to December 2017 (UAS flight two), and December 2017 to April 2018 (UAS flight three), and then across the full study period, 2014 to April 2018 (Table 2). March 2017 (UAS flight one) to September 2017 (lidar) values are not included in the analysis as the absolute error between these two surfaces was too large. 


\subsection{Sediment Composition and Wind Data}

In the summer of 2018,58 cores were collected to quantify grain distributions. A core was collected at each vegetated pin to a depth of $1 \mathrm{~m}$. An additional 20 cores, sampled to $50 \mathrm{~cm}$ in depth, were collected from the backshore $10 \mathrm{~m}$ from the dune toe and longitudinally aligned with the 20 vegetated pins that were spaced $75 \mathrm{~m}$ apart in the southern survey half. All cores were collected with a T-core sampler of 30-cm tube length. Samples were dried, then sorted for $5 \mathrm{~min}$ in a RX-29 Ro-Tap ${ }^{\circledR}$ cascade shaker, using eight different US Standard Sieve Mesh Sizes, mesh \#25 (0.71 mm, $\Phi 0.5)$, \#35 (0.50 mm, 11.0$)$, \#45 (0.35 mm, $\Phi 1.5)$, \#60 (0.25 mm, $\Phi 2.0)$, \#70 (0.21 mm, $\Phi 2.25)$, \#100 (0.149 mm, 2.75$)$, \#140 (0.105 mm, $\Phi 3.25)$, and the bottom pan $(<0.105 \mathrm{~mm}, \Phi>3.25)$. Raw sieve weights were processed using SANDY to generate mean grain size, kurtosis, and skewness values per sample [60]. See Supplemental 4 for more details on sediment distributions.

Wind velocity and weather (precipitation and temperature) data from 2015 to 2018 were collected from the nearest Rutgers NJ Weather Network station (Seaside Heights). The sensor is $14 \mathrm{~km}$ north of the northern study extent on the barrier island at $12 \mathrm{~m}$ elevation $(-74.0738,39.94383)$. These data are largely continuous, where data gaps (i.e., sensor outages) in one or more parameters were supplemented from the nearby Harvey Cedars or Sea Girt stations. See Supplemental 5 for more details on station sensors, outages, and wind velocity presented as wind roses [61], produced in MATLAB ${ }^{\circledR}$ over the study duration [62]. Data are at 5-min intervals and corrected from sensor height to surface level using von Karman's law of the wall equation [63].

$$
\begin{gathered}
U_{*}=\left[\frac{U_{z}}{\ln \left(\frac{z}{z_{0}}\right)}\right] \cdot k \\
z_{0}=0.035 \times \ln \left(\frac{d}{0.18}\right)
\end{gathered}
$$

where $z=$ sensor height in meters, $U_{z}=$ wind velocity at the sensor height in $\mathrm{m} / \mathrm{s}, z_{0}=$ the grain size roughness length, $\mathrm{K}=0.4, d=$ sediment size in meters.

Wind data was categorically defined as coming from the northeast $\left(0^{\circ}\right.$ to $\left.90^{\circ}\right)$, southeast $\left(91^{\circ}\right.$ to $\left.180^{\circ}\right)$, southwest $\left(181^{\circ}\right.$ to $\left.270^{\circ}\right)$, or northwest $\left(271^{\circ}\right.$ to $\left.360^{\circ}\right)$ quadrant as well as onshore $\left(0^{\circ}\right.$ to $\left.180^{\circ}\right)$ or offshore $\left(181^{\circ}\right.$ to $\left.360^{\circ}\right)$. The number of instances whereby wind speed was at or above the critical velocity for entrainment was determined by first correcting for the elevation difference between the instrument and ground level [14]. Next, the critical Shield threshold for initiation of motion for the maximum $d 50(0.23 \mathrm{~mm})$ at the site was calculated as:

$$
U_{* c r}=A \sqrt{\frac{\rho_{s}-\rho}{\rho} g d}
$$

where $A=0.1, \rho=1.225 \mathrm{~kg} / \mathrm{m}^{3}, g=9.81 \mathrm{~m} / \mathrm{s}^{2}$, and $\left(d=0.2 \mathrm{~mm}, \rho_{s}=2650 \mathrm{~kg} / \mathrm{m}^{3}\right.$, for quartz sand), not corrected for beach slope, air temperature, or humidity. Using Equation (3), the critical velocity was $0.22 \mathrm{~m} / \mathrm{s}$ for the largest grains sampled [64]. Wind roses were created using this critical velocity to determine when sediment motion was possible and delineated with respect to concomitant precipitation events, as well.

\subsection{Statistical Analyses}

Unless otherwise noted, all tests are two-tailed with $\alpha=0.05$ and were performed with JMP Pro 15.0 or Microsoft Excel 2016. All means are \pm standard error. All wind roses were created in MATLAB ${ }^{\circledR}[61,62] . \Delta z$ was typically evaluated as the absolute value $(|\Delta z|)$, categorized as erosional or accretional, given that both erosive and accretive instances occurred concomitantly within and among the collections. 


\subsubsection{Microscale Analyses}

Analyses on microscale $\Delta z$ or $|\Delta z|$ test its variability across seasons (fall, winter, spring, summer), collection types (event-based, seasonal, or monthly), and elevation pin types (vegetated, unvegetated, transitional). Pin types and collection durations used in the different tests balance sample sizes and time between collections relative to the hypotheses in question. Where noted, instances of no net change $(\Delta z=0)$ were not included to prevent a loss of degrees of freedom. Instances of no net change were random and evenly distributed across the pin types. Comparisons between groups in multivariate analyses are Tukey HSD pairwise comparisons.

\section{General Variation between Collection Types}

ANOVA was used to examine if transition pin $|\Delta z|$, between collections and over their install duration (collection 11 to 27) varied based on their position in the north or south side of the east blowout wall and by aspect (N, S, NE, or SE facing). Linear regression was performed to test if days between collections impact mean $\Delta z$ period 1-26 for the unvegetated data. Fisher's exact tests were used to test if categorical instances of erosion or accretion occurred more or less than would be expected by chance.

\section{Month-to-Month Seasonal Variation Analyses}

$|\Delta z|$ seasonal variability, month-to-month and in different seasons, was tested with full factorial multivariate regressions. The independent variables are change type (erosion or accretion) and season. This test was performed using only the monthly unvegetated data from collections 4 to 18 - a full year-excluding instances of no net change, where periods $4-6$ and $16-18,7-9,10-12$, and 13-15 represent spring, summer, fall, and winter, respectively (Table 1); the test was rerun with period 10 excluded as a potential outlier.

\section{Vegetation Impact Analyses}

Seasonal variability was analyzed with pin type to test if and how vegetation impacted $\Delta z$. Monthly collections with all pin types present did not span a full year (Table 1 ), so that $|\Delta z|$ was analyzed from seasons' start to end, as in collections 13-16, 16-19, 19-20, and 20-21, as the winter, spring, summer, and fall of 2017, respectively, and 22-25 and 25-26 as the spring and summer of 2018, respectively (Table 1 ). Three tests using combinations of the above data were performed to ensure results were robust across time: (1) all six seasons were used with uneven sample sizes, given more spring and summer replicates, (2) four 2017 seasons were used, and (3) collections from the winter and fall of 2017 were analyzed with those from spring and summer of 2018. The three tests were full-factorial multivariate regressions, excluding change type as an independent variable, given that it and interactions including it were not significant.

The vegetation impact was tested in event-based and monthly collections. A fullfactorial multivariate regression was performed on $|\Delta z|$ with the independent variables of change type, pin type, and period (for periods 20, 23, 24, and 26, all three pin types were installed and observed an event); an event did not occur in period 22, so that period 22 and general instances of no change were excluded. The same full-factorial multivariate regression was also performed on $|\Delta z|$ in the monthly collections (period 11 to 18 , all pin types present). Lastly, from the first collection with all pin types to the last such (collections 11 to 27$)$, the difference in total $\Delta z$ was examined with ANOVA; outliers $(n=7)$, defined as two or more standard deviations from the mean for each pin type, were excluded. Examining the potential impact of different vegetation-cover types and densities is outside of the scope of this research but will be examined in a subsequent publication. For reference, the vegetated pins maintained a density of $107 \pm 9$ plants and $48 \% \pm 2.8 \%$ cover $\left(1 \mathrm{~m}^{2}\right.$ transect, with the pin in the middle) where transition pins maintained similar density and percent cover in half the transect and were bare the other half. 


\subsubsection{Mesoscale Analyses}

Mesoscale analyses link microscale and mesoscale metrics and quantify the impact of beach access paths on $\Delta z$. $\Delta z$ quantified from complimentary UAS (flights one to two, two to three, and one to three) and field data (collections 16 to 21,21 to 24 , and 16 to 24) were compared between the remote versus field data using Wilcoxon tests. Missing data from one dataset are excluded from the other to balance the sample sizes, accounting for instances of missing pins and areas of poor image stitching in the field and remote data, respectively. Outliers, defined as having $\Delta z$ greater than $150 \mathrm{~cm}$ relative to the vertical uncertainty of the remote datasets were excluded from these tests. Kruskal-Wallis tests were performed per flight period to compare spatial sensitivity radii across pin types.

Beach impacts were categorized as $\Delta z$ accretional or erosional at access impact areas and were compared with Mann-Whitney tests against the access impact geometries. Access impact locations (crest, head, middle) were examined as impacting geometries using Kruskal-Wallis tests. Beach-access impact geometries are defined as the major axis orientation relative to true north, polygonal minor axis distance (i.e., width), polygonal major axis distance (i.e., length), polygonal perimeter distance, and polygonal surface area.

\section{Results}

\subsection{Site Characteristics during Survey Periods}

Mean beach width and standard deviation decreased overall from 2014 to April 2018 (72 $\pm 255 \mathrm{~m}$ to $63 \pm 150 \mathrm{~m}$, respectively; Figure S2.4. This decrease corresponded with an overall shallowing of the mean foreshore slope from $40-50^{\circ}$ to $0-15^{\circ}$, with the foreshore slope aspect, relative to true north, ranging from $67.5^{\circ}$ to $112.5^{\circ}$. The study area experienced a mean accretional $\Delta z$ of $+0.56 \pm 2.42 \mathrm{~m}$ and normalized volumetric change of $+0.12 \pm 0.003 \mathrm{~m}^{3} / \mathrm{m}^{2}$ from 2014 to April 2018.

The site experienced wind speeds greater than critical sediment mobility for $3.8 \%$ of the 4-year records. The majority of mobility periods, $83 \%$, occurred during times of no precipitation and occurred in two main directional sectors: $45-135^{\circ}$ (NE-SE, stronger speeds) and $285-10^{\circ}$ (NNW-NNE, more frequent). These sectors align with the predominant winter storm (extra-tropical cyclones) and tropical cyclone wind directions in this area. See Supplemental 5 for additional details of the aeolian analysis.

\subsection{Microscale Measured Variation between Collection Types}

When all three pin types were installed, period 11 , on both $\Delta z\left(F_{2,1017}=15.26\right.$, $p<0.0001)$ and $|\Delta z|\left(F_{2,1017}=18.11, p<0.0001\right)$ varied by collection type and were greater in event-based than monthly and seasonal collections. Event-based collections were primarily more accretional than would be expected by chance, whereas monthly collections were primarily erosional, and seasonal collections did not have more or fewer instances of erosion or accretion than would be expected by chance (Fisher's Exact Test, $p<0.0001$ ). Transition pin location on the east wall and aspect did not impact $\Delta z(p>0.05)$ and $\Delta z$ between collections was unrelated to time between collections in unvegetated pins $\left(R^{2}=0.10\right.$, $p>0.05)$.

\subsection{Microscale Measured Month-to-Month Seasonal Variation}

Unvegetated pins' month-to-month $|\Delta z|$ variation was seasonally dependent $\left(\mathrm{F}_{3,170}=10.73, p<0.0001\right)$. They also varied between erosional and accretional occurrences $\left(F_{1,170}=11.04, p<0.0001\right)$, with a significant season $X$ change-type interaction $\left(\mathrm{F}_{3,170}=5.68, p=0.0001\right)$ stemming from greater $|\Delta z|$ in fall $(12.5 \pm 3.1 \mathrm{~cm})$ than in other seasons $(4.7 \pm 0.5 \mathrm{~cm})$, where the differences in accretional $|\Delta z|(9.35 \pm 1.17 \mathrm{~cm})$ versus erosional instances $(4.28 \pm 0.98 \mathrm{~cm})$ were driven by fall collections. These results remained true when excluding period 10 as a potential outlier.

Seasonal differences, in the above unvegetated analyses, stemmed from wind direction in instances above critical velocity (Figure 3). Mean wind speed during these periods was similar from all directions (NE, SE, NW, and SW) with speeds between $0.25-0.28 \mathrm{~m} / \mathrm{s}$ and 
the greatest wind speeds having occurred in spring and winter. Fall was the only time when northeast winds were predominant (44\% of instances) and of greater magnitude, compared with other seasons, when northwestern winds were predominant (40-54\% of instances; Figure 3A). Analyzing fall wind speed in (period 10-12), mean $\Delta z$ in period 10 $(20.03 \pm 4.69 \mathrm{~cm})$, when northeastern winds predominated, was more than double period $11(7.58 \pm 4.06)$ and $12(4.94 \pm 3.83)$, despite equivalent wind speeds from other directions (Figure 3B). Spring 2016 and 2017 had nearly identical wind directions, but greater wind speeds in 2017, yet equivalent $\Delta z\left(\mathrm{t}_{80}=0.31, p=0.75\right.$; Figure 3A,C). Northeastern winds encompassed $22 \%, 30 \%, 44 \%$, and $23 \%$ of instances in spring, summer, fall, and winter, respectively.

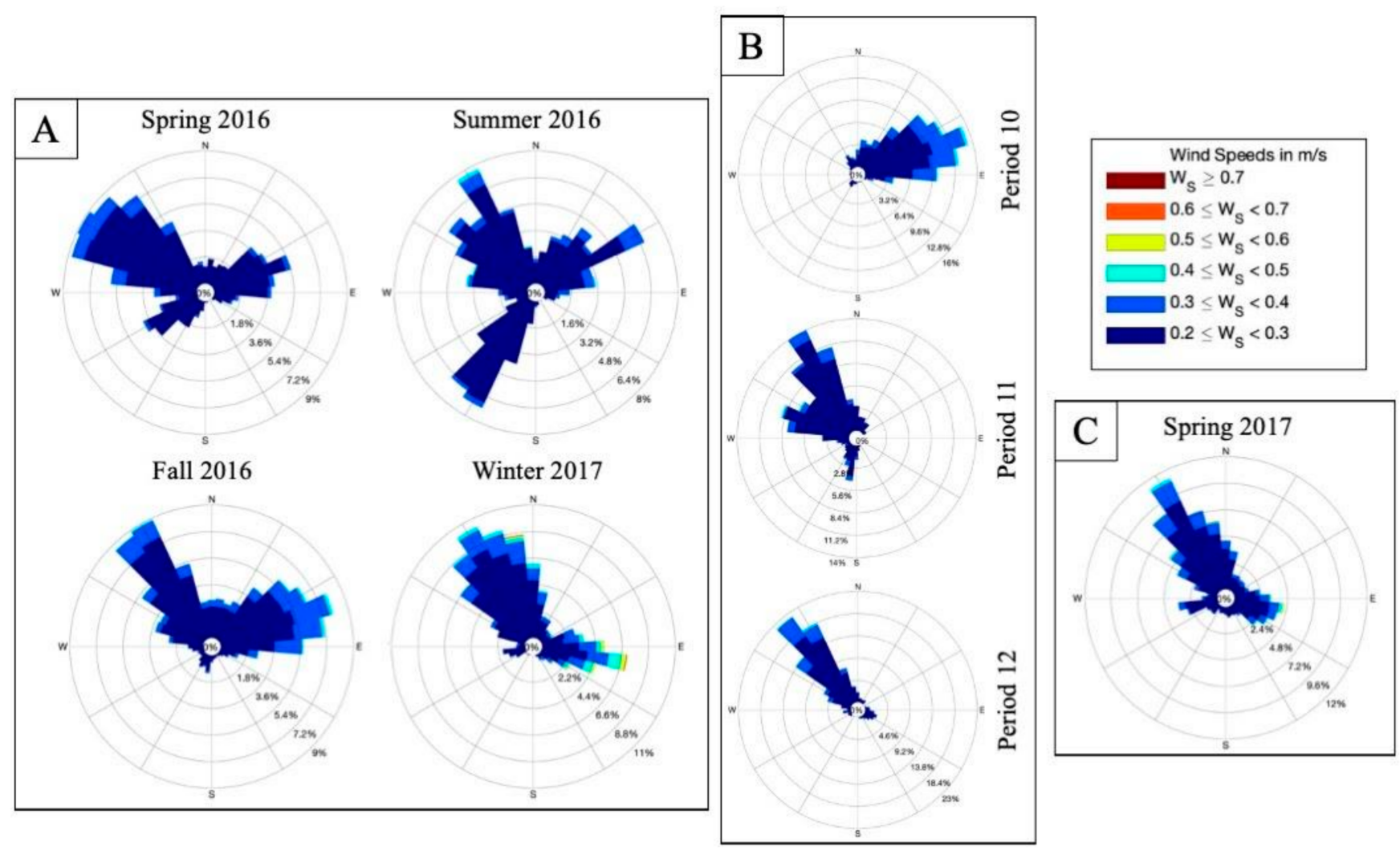

Figure 3. A subset of wind roses showing collection periods, seasonal, and annual wind velocities above the critical threshold of motion for the measured sediment grain size. (A) Seasonal wind roses for the 2016-2017 period. (B) Three wind roses for the fall of 2016, showing the variability of wind velocity between monthly collections compared to the overall seasonal winds (Fall 2016, plot A). (C) Seasonal wind rose for spring 2017 as an annual comparison to spring 2016 (plot A). All plots use the same scale shown in the upper right corner.

\subsection{Impacts of Vegetation on Microscale Measurements}

Variation in $|\Delta z|$ across seasons, by pin type, consistently supports vegetation as reducing sediment movement (i.e., increasing stability; Table 3). In all three seasonal tests using different temporal data, $|\Delta z|$ varied by pin type, with transition pins not varying from either the vegetated or unvegetated pins, but the vegetated pins having lower $|\Delta z|$ than unvegetated pins (Figure 4A; Table 3). Pairwise differences between the seasons varied with the data used in tests 1,2 , and 3 . 
Table 3. Variation in $|\Delta z|$ across seasons by pin type consistently supports vegetation as reducing sediment movement with pairwise differences across seasons, based on which subset of the temporal data was analyzed. Analyses were full factorial multivariate regressions. Season and pin type never had a significant interaction $(p>0.05)$.

\begin{tabular}{|c|c|c|c|}
\hline & Variation in $|\Delta z|$ & Statistical Test & Pairwise Comparisons \\
\hline $\begin{array}{l}\text { Seasonal Test } 1: \\
\text { All } 6 \text { seasons }\end{array}$ & \multirow{3}{*}{$\begin{array}{c}\text { transitional = unvegetated and } \\
\text { vegetated pins; }\end{array}$} & $\begin{array}{l}\mathrm{F}_{2,395}=8.35 \\
p<0.001\end{array}$ & $\begin{array}{l}\text { fall }>\text { spring and summer } \\
\left(\mathrm{F}_{3,395}=7.82, p<0.0001\right)\end{array}$ \\
\hline $\begin{array}{l}\text { Seasonal Test 2: } \\
2017 \text { data }\end{array}$ & & $\begin{array}{l}\mathrm{F}_{2,63}=4.91 \\
p<0.01\end{array}$ & $\begin{array}{l}\text { No pairwise seasonal } \\
\text { differences }\end{array}$ \\
\hline $\begin{array}{l}\text { Seasonal Test 3: } \\
2017 \text { and } 2018 \text { Combined }\end{array}$ & & $\begin{array}{l}\mathrm{F}_{2,262}=3.89 \\
p=0.02\end{array}$ & $\begin{array}{l}\text { spring }>\text { summer and Fall } \\
\left(\mathrm{F}_{3,262}=12.70, p<0.0001\right)\end{array}$ \\
\hline
\end{tabular}
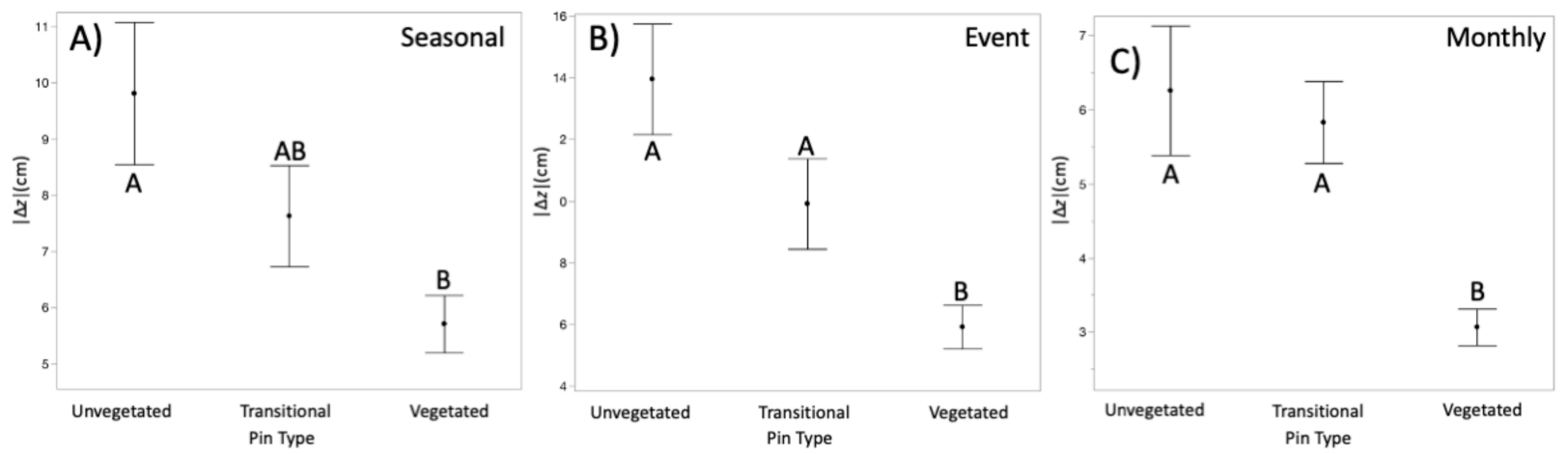

Figure 4. Variation in $|\Delta z|$ between pin types. Across the three types of collections, (A) seasonal, (B) event-based, and monthly $(\mathbf{C})$ there was consistently less $|\Delta z|$ in the vegetated pins compared with the unvegetated and transitional pins. Mean differences across pin types hold, regardless of whether $|\Delta z|$ was equivalent between instances of erosion versus accretion (e.g., seasonal and monthly) or accretion was of a greater magnitude (e.g., events). Error bars are standard error and pin types with different letters denoting a significant difference between pin types (Tukey HSD).

Variation in $|\Delta z|$ during event-based and monthly collections supported vegetation stabilization. During events, $|\Delta z|$ varied by pin type $\left(\mathrm{F}_{2,218}=10.89, p<0.0001\right)$ with vegetated pins having less $|\Delta z|$ than both the transition and unvegetated pins (Figure 4B) and the magnitude of $|\Delta z|$ was greater in instances of accretion than erosion $\left(\mathrm{F}_{1,218}=4.56\right.$, $p=0.03)$. $|\Delta z|$ did not vary between the four event periods $(p=0.83)$. In monthly collections, vegetated pins had less $|\Delta z|$ than both the transition and unvegetated pins $\left(\mathrm{F}_{2,459}=12.81, p<0.0001 ;\right.$ Figure $\left.4 \mathrm{C}\right)$ and the magnitude of $|\Delta z|$ was equal in instances of erosion and accretion $(p=0.29)$. There were no significant interactions in either the seasonal or monthly multivariate regression tests.

Across the study duration, from the first collection with all three pin types to the final collection (11 to 27$), \Delta z$ varied by pin type $\left(\mathrm{F}_{2,59}=8.51, p<0.001\right)$, with vegetated pins having greater $\Delta z$ than both the transition and unvegetated pins (Figure 5). Variation in $\Delta z$ across collection and pin types are presented in Table 4. Instances of erosion and accretion were equally spread across the pin types, as would be expected by chance in monthly and seasonal collections, but the monthly collection transitional and unvegetated pins had more instances of erosion and fewer instances of accretion than would be expected by chance, whereas the opposite was true for vegetated pins in these same monthly collections (Fisher's exact test, $p<0.0001$ ). 


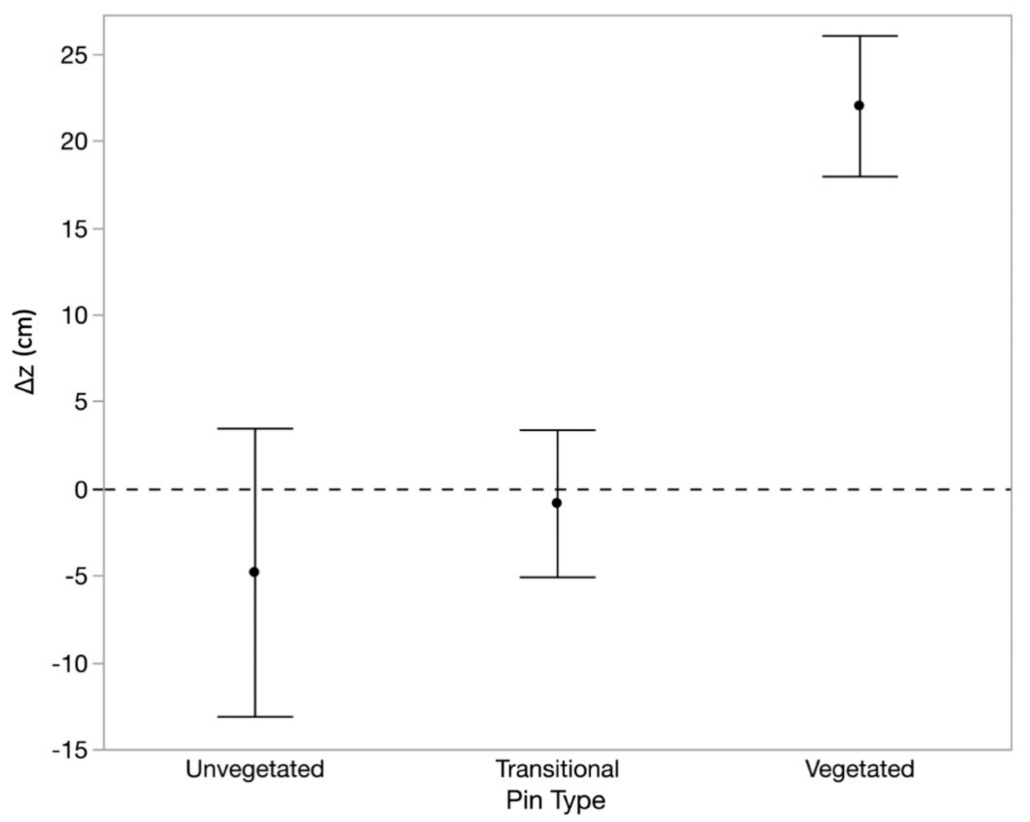

Figure 5. Total $\Delta z$, from the first collection with all three pin types to the final collection (collections 11 through 27, from October 2016 to September 2018). Despite less incremental $\Delta z$, erosional or accretional, season to season and during events throughout their installment, the vegetated pins accreted more than both the unvegetated and transitional pins. Error bars are standard error.

Table 4. Vegetated pins consistently had less $\Delta z(\mathrm{~cm})$, regardless of collection type, but greater $\Delta z$ increase over the duration of the install (Total $\Delta z$ ) of all three pin types, collection 11 to 27. Differences between $\Delta z$ and $|\Delta z|$ highlight the importance of performing analyses on $|\Delta z|$ given that instances of both positive and negative values in $\Delta z$ otherwise obscure the results. Units are $\mathrm{cm}$ and means are presented with standard error.

\begin{tabular}{|c|c|c|c|c|c|c|c|}
\hline Pin Type & $\begin{array}{c}\text { Collection } \\
\text { Type }\end{array}$ & $\begin{array}{c}\operatorname{Min} \\
\Delta z\end{array}$ & $\begin{array}{c}\operatorname{Max} \\
\Delta z\end{array}$ & $\begin{array}{c}\text { Mean } \\
\Delta z\end{array}$ & $\begin{array}{c}\text { Mean } \\
|\Delta z|\end{array}$ & $\begin{array}{l}\text { Accretion } \\
\text { Mean } \Delta z\end{array}$ & $\begin{array}{c}\text { Erosion } \\
\text { Mean } \Delta z\end{array}$ \\
\hline $\begin{array}{c}\mathrm{u} \\
\text { transitional } \\
\text { vegetated }\end{array}$ & event & $\begin{array}{l}-47.4 \\
-37.2 \\
-16.5\end{array}$ & $\begin{array}{c}106.7 \\
68.6 \\
40.6\end{array}$ & $\begin{array}{c}11.2 \pm 2.6 \\
4.2 \pm 1.3 \\
4.3 \pm 0.7\end{array}$ & $\begin{array}{c}17.2 \pm 2.3 \\
7.5 \pm 1.1 \\
5.4 \pm 0.6\end{array}$ & $\begin{array}{c}23.0 \pm 3.5 \\
10.4 \pm 1.7 \\
7.0 \pm 0.8\end{array}$ & $\begin{array}{l}-10.3 \pm 1.8 \\
-5.9 \pm 1.5 \\
-4.6 \pm 1.2\end{array}$ \\
\hline $\begin{array}{c}\text { unvegetated } \\
\text { transitional } \\
\text { vegetated }\end{array}$ & seasonal & $\begin{array}{l}-30.1 \\
-40.6 \\
-54.6\end{array}$ & $\begin{array}{c}7.7 \\
29.6 \\
33.7\end{array}$ & $\begin{array}{c}-1.8 \pm 0.9 \\
1.6 \pm 1.0 \\
2.0 \pm 0.8\end{array}$ & $\begin{array}{l}3.6 \pm 0.7 \\
5.0 \pm 1.1 \\
4.4 \pm 0.8\end{array}$ & $\begin{array}{l}2.7 \pm 0.6 \\
3.9 \pm 1.1 \\
5.8 \pm 1.0\end{array}$ & $\begin{array}{l}-5.5 \pm 1.3 \\
-6.9 \pm 2.0 \\
-6.1 \pm 2.4\end{array}$ \\
\hline $\begin{array}{l}\text { unvegetated } \\
\text { transitional } \\
\text { vegetated }\end{array}$ & monthly & $\begin{array}{l}-37.3 \\
-36.8 \\
-17.8\end{array}$ & $\begin{array}{l}71.1 \\
35.6 \\
27.9\end{array}$ & $\begin{array}{c}-0.5 \pm 0.6 \\
-1.0 \pm 0.7 \\
0.6 \pm 0.3\end{array}$ & $\begin{array}{l}4.6 \pm 0.5 \\
5.3 \pm 0.5 \\
2.4 \pm 0.2\end{array}$ & $\begin{array}{l}7.1 \pm 1.4 \\
5.4 \pm 0.9 \\
3.1 \pm 0.3\end{array}$ & $\begin{array}{l}-5.0 \pm 0.6 \\
-6.2 \pm 0.7 \\
-3.1 \pm 0.4\end{array}$ \\
\hline $\begin{array}{c}\text { unvegetated } \\
\text { transitional } \\
\text { vegetated }\end{array}$ & total $\Delta z$ & $\begin{array}{l}-40.0 \\
-25.4 \\
-45.7\end{array}$ & $\begin{array}{l}41.9 \\
35.6 \\
61.6\end{array}$ & $\begin{array}{c}-4.8 \pm 8.3 \\
-0.8 \pm 16.9 \\
22.0 \pm 4.1\end{array}$ & $\begin{array}{l}28.2 \pm 3.1 \\
13.4 \pm 2.4 \\
25.8 \pm 3.2\end{array}$ & $\begin{array}{l}27.3 \pm 4.1 \\
11.1 \pm 3.7 \\
26.6 \pm 3.3\end{array}$ & $\begin{array}{l}-28.9 \pm 4.6 \\
-16.2 \pm 2.8 \\
-19.1 \pm 13.5\end{array}$ \\
\hline
\end{tabular}

\subsection{Microscale to Mesoscale Metric Linking}

The mesoscale UAS data largely differed from field pin collections in accurately quantifying the direction and magnitude of $\Delta z$ (Figure 6). Categorically, the remote sensing data were in agreement with the field measurements for the type of change occurring (i.e., erosion, accretion, or no change) in $71 \%, 51 \%$, and $71 \%$ of instances over flights one to two, two to three, and one to three, respectively. Correct versus incorrect instances were evenly split across pin types, varying slightly by survey period. In instances of categorical congruence and incongruence between the two data types, the UAS surface overestimated $\Delta z$ flight one to two and one to three. In flights two to three, the UAS surface 
underestimated $\Delta z$ compared reality in instances of categorical incongruence and was equal for instances of congruence (Table 5).

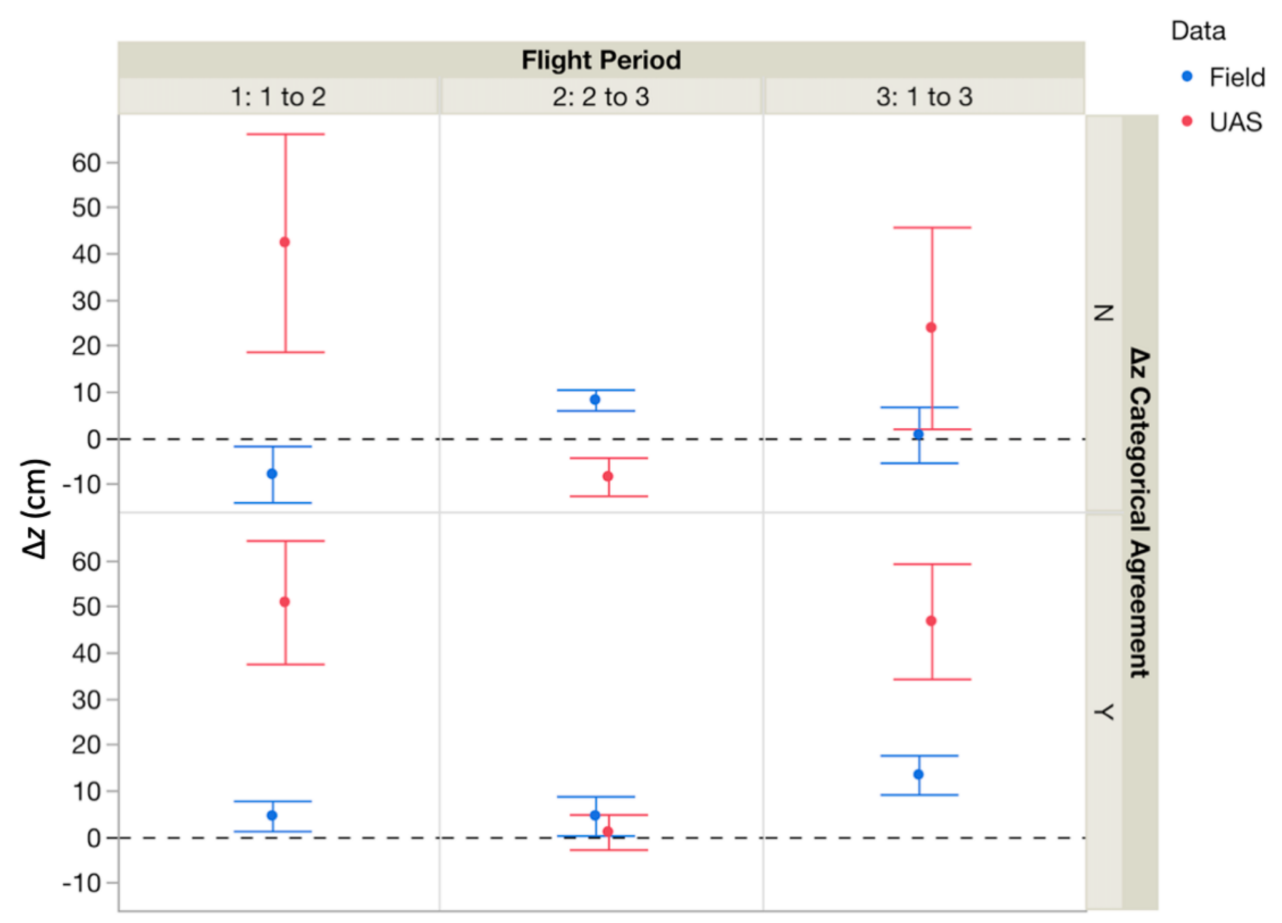

Figure 6. The UAS surfaces typically overestimated the magnitude of $\Delta z(\mathrm{~cm})$ relative to the field elevation pin measurements, regardless of whether the two data types were in agreement with the type of change-erosional or accretional-that occurred. Over-estimation ranged from 3-34x the true magnitude observed in situ. Slight differences in collection times could theoretically account for some of these differences, but not to the degree observed given that microscale data show minimal changes in elevation in the absence of an event and there were no events between the temporal incongruence of the datasets.

Table 5. Variation in $\Delta \mathrm{z}$ calculated from the UAS surface versus pins between flights.

\begin{tabular}{|c|c|c|c|c|c|}
\hline & & $\begin{array}{l}\text { UAS Surface } \Delta z \text { vs. } \\
\text { Actual (Pin) } \Delta z\end{array}$ & Mean UAS $\Delta z$ & Mean Pin $\Delta z$ & $\begin{array}{l}\text { Wilcoxon Test } \\
\text { Result }\end{array}$ \\
\hline Flights 1 to 2 & \multirow{3}{*}{$\begin{array}{c}\text { instances of categorical } \\
\text { incongruence between } \\
\text { data types }\end{array}$} & \multirow{2}{*}{$\begin{array}{l}\text { UAS surface } \\
\text { overestimated } \Delta z\end{array}$} & $28.96 \pm 23.3 \mathrm{~cm}$ & $-7.83 \pm 6.11 \mathrm{~cm}$ & $\mathrm{Z}=2.31, p=0.02$ \\
\hline Flights 1 to 3 & & & $23.85 \pm 21.88 \mathrm{~cm}$ & $0.70 \pm 6.05 \mathrm{~cm}$ & $Z=0.84, p=0.40$ \\
\hline Flights 2 to 3 & & $\begin{array}{l}\text { UAS surface } \\
\text { underestimated } \Delta z\end{array}$ & $-8.39 \pm 4.14 \mathrm{~cm}$ & $8.23 \pm 2.25 \mathrm{~cm}$ & $Z=-4.28, p<0.0001$ \\
\hline Flights 1 to 2 & \multirow{3}{*}{$\begin{array}{c}\text { instances of categorical } \\
\text { congruence between } \\
\text { data types }\end{array}$} & \multirow{2}{*}{$\begin{array}{l}\text { UAS surface } \\
\text { overestimated } \Delta z\end{array}$} & $56.88 \pm 13.13 \mathrm{~cm}$ & $4.51 \pm 3.27 \mathrm{~cm}$ & $Z=4.26, p<0.0001$ \\
\hline Flights 1 to 3 & & & $46.78 \pm 12.48 \mathrm{~cm}$ & $13.41 \pm 4.23 \mathrm{~cm}$ & $\mathrm{Z}=4.15, p<0.0001$ \\
\hline Flights 2 to 3 & & $\begin{array}{l}\text { UAS surface \& } \\
\text { actual equal }\end{array}$ & $2.77 \pm 2.83 \mathrm{~cm}$ & & $\mathrm{Z}=4.15, p<0.0001$ \\
\hline
\end{tabular}

Differences in $\Delta z$ across pin types (i.e., attributable to vegetation impacts) were not observable in the mesoscale data. Similarly, looking at microscale $\Delta z$, as a whole, from one flight to the next showed equivalent $\Delta z$ across pin types, stemming from the high standard error associated with the means per group $(p>0.05)$.

Across flights, the spatial sensitivity analyses largely showed agreement between pin types regarding the distance beyond a pin at that $\Delta z$ switched categorically from erosional to accretional or vice versa. The datasets maintain the same change category 
for $\bar{x}=16.48 \pm 1.15 \mathrm{~m}$ and $\bar{x}=13.73 \pm 1.09 \mathrm{~m}$ over flights one to two and one to three, respectively, with no differences across pin types $(p>0.05)$. Only for flights two to three does the range of data sensitivity vary across pin types (Figure 7).

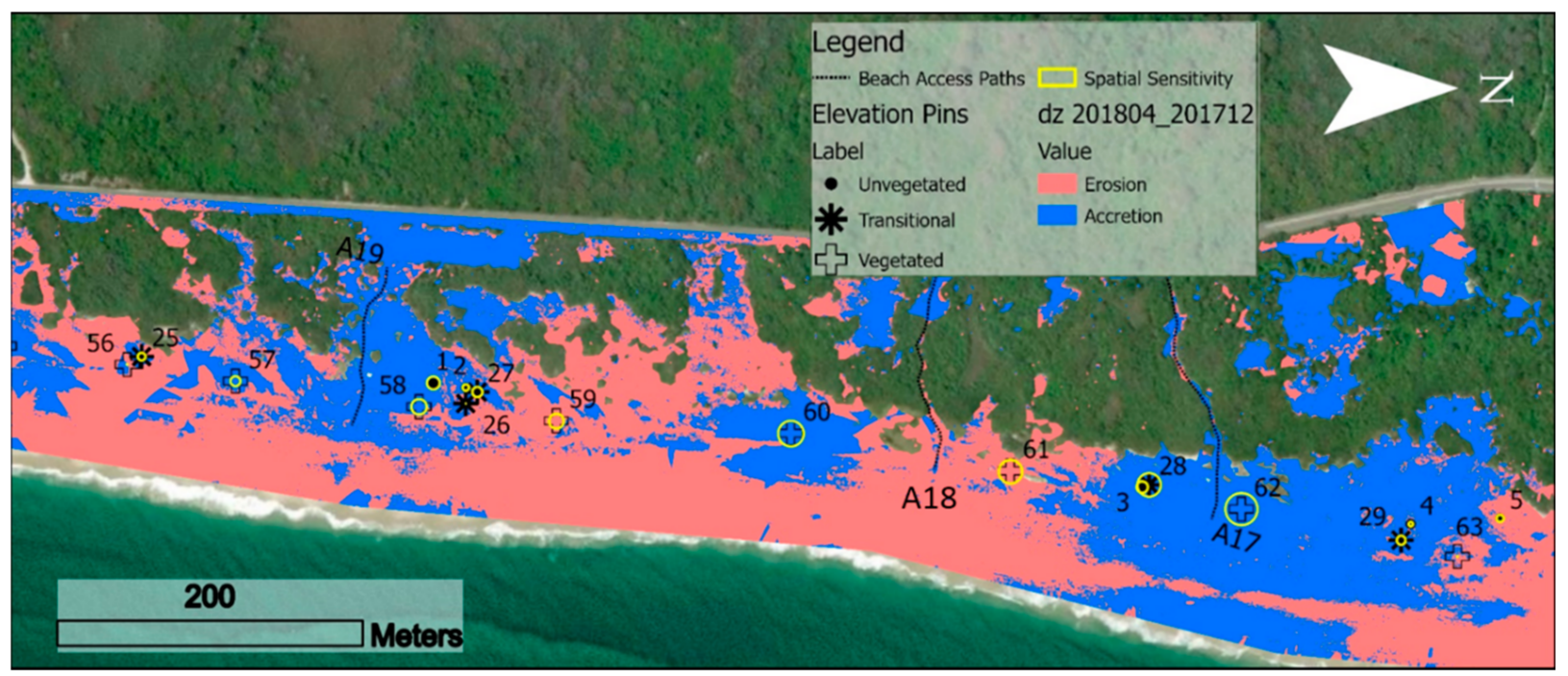

Figure 7. A zoomed view (accesses 19 to 17) of spatial sensitivity analysis showing measured buffers (yellow circles) around numbered elevation pins (symbols) overlain on a categorical $\Delta z$ map from flights two to three, April 2018 to December 2017. Forested areas were masked and excluded. Only between flights two to three was there a difference in radii, with vegetated pins showing a wider radius than both the transitional and unvegetated areas (Kruskal-Wallis Test, $\bar{x}_{V}=4.57 \pm 0.78 ; \bar{x}_{T}=1.75 \pm 0.47 ; \bar{x}_{U}=1.37 \pm 0.52 ; X^{2}=13.64, p=0.001$ ). (Kruskal-Wallis Test, $\bar{x}_{V}=4.57 \pm 0.78$; $\left.\bar{x}_{T}=1.75 \pm 0.47 ; \bar{x}_{U}=1.37 \pm 0.52 ; \mathrm{X}^{2}=13.64, p=0.001\right)$.

\subsection{Beach Access Path Impacts on Local Topographic Change}

Throughout the study, from 2014 to April 2018, 38 individual polygons were identified as increased areas of dynamism linked to accesses (37\% erosional and $63 \%$ accretional). Of the erosional areas, $15.8 \%, 13.2 \%$, and $7.9 \%$ occurred at the path's crest, middle, and termination head, respectively. Of the accretional areas, $18.4 \%, 28.9 \%$, and $15.8 \%$ occurred at the path's crest, middle, and termination head, respectively. The identified access impacts began at the crests in 2014 and migrated inland towards the heads of each access path by April 2018.

Access-impact geometries shifted over each survey period. The mean width and length of impact areas increased on each subsequent survey, while orientation shifted eastward (Table 6). Sinuosity calculations for the 12 access paths generated a mean value of 1.05, indicating linear paths. The number of impact areas decreased from the mesoscale survey periods one to two, while their sizes (width, length, and surface area) increased (Table 6), suggesting the impact areas coalesced into fewer, larger areas. In the subsequent mesoscale period (period three), it is not clear whether, relative to period two, the previously existing impact areas separated and grew or additional impact areas formed (Table 5). 
Table 6. Mean \pm standard error for access impact polygon geometries during the survey periods, 2014 to April 2018. Orientation is reported in degrees from true north, and surface area as the summed surface area of the identified impact polygons.

\begin{tabular}{ccccc}
\hline & \multicolumn{4}{c}{ Survey Period } \\
\cline { 2 - 5 } & $\begin{array}{c}\mathbf{1 :} \mathbf{2 0 1 4} \text { to } \\
\text { September 2017 }\end{array}$ & $\begin{array}{c}\text { 2: September 2016 to } \\
\text { December 2017 }\end{array}$ & $\begin{array}{c}\text { 3: December 2017 to } \\
\text { April 2018 }\end{array}$ & $\begin{array}{c}\text { 4: 2014 } \\
\text { to April 2018 }\end{array}$ \\
\hline impact polygons & 34 & 24 & 35 & 38 \\
identified $(n)$ & $5.4 \pm 0.9$ & $8.1 \pm 1.3$ & $8.9 \pm 1.2$ & $9.9 \pm 1.3$ \\
width (m) & $11.8 \pm 1.8$ & $18.3 \pm 3.4$ & $17.4 \pm 2.5$ & $27.6 \pm 2.4$ \\
length (m) & 2677 & 4515 & 6084 & 11,610 \\
surface area $\left(\mathrm{m}^{2}\right)$ & $77.2 \pm 8.8$ & $84.6 \pm 9.2$ & $86.4 \pm 7.8$ & $90.7 \pm 7.9$ \\
orientation $\left({ }^{\circ}\right)$ & & & & \\
\hline
\end{tabular}

Paths' crest, middle, and head areas had largely equal impact-geometry metrics. In mesoscale period one (2014 to September 2017), impact areas occurred at all paths' crests and middles, while no effects were identified at paths' inland termination heads (Figure 8); specifically, crests had larger impact areas-more than double, in most instances-than paths' middles for all geometries, except orientation, which did not vary locally along paths: width $\left(\bar{x}_{C}=25.3 \pm 5.0 \mathrm{~m}, \bar{x}_{M}=11.6 \pm 2.7 \mathrm{~m}, \mathrm{Z}=2.19, p=0.029\right)$, length $\left(\bar{x}_{C}=56.5 \pm 10.2 \mathrm{~m}\right.$, $\left.\bar{x}_{M}=24.4 \pm 5.1 \mathrm{~m}, \mathrm{Z}=2.47, p=0.014\right)$, perimeter $\left(\bar{x}_{C}=137.2 \pm 23.4 \mathrm{~m}, \bar{x}_{M}=60.8 \pm 12.9 \mathrm{~m}\right.$, $\mathrm{Z}=2.47, p=0.014)$, and surface area $\left(\bar{x}_{C}=1428 \pm 373 \mathrm{~m}^{2}, \bar{x}_{M}=360 \pm 175 \mathrm{~m}^{2}, \mathrm{Z}=2.45\right.$, $p=0.014)$. For the other mesoscale survey periods, there were no difference between access impact geometries, locally, among the heads, middles, or crests of beach access paths.
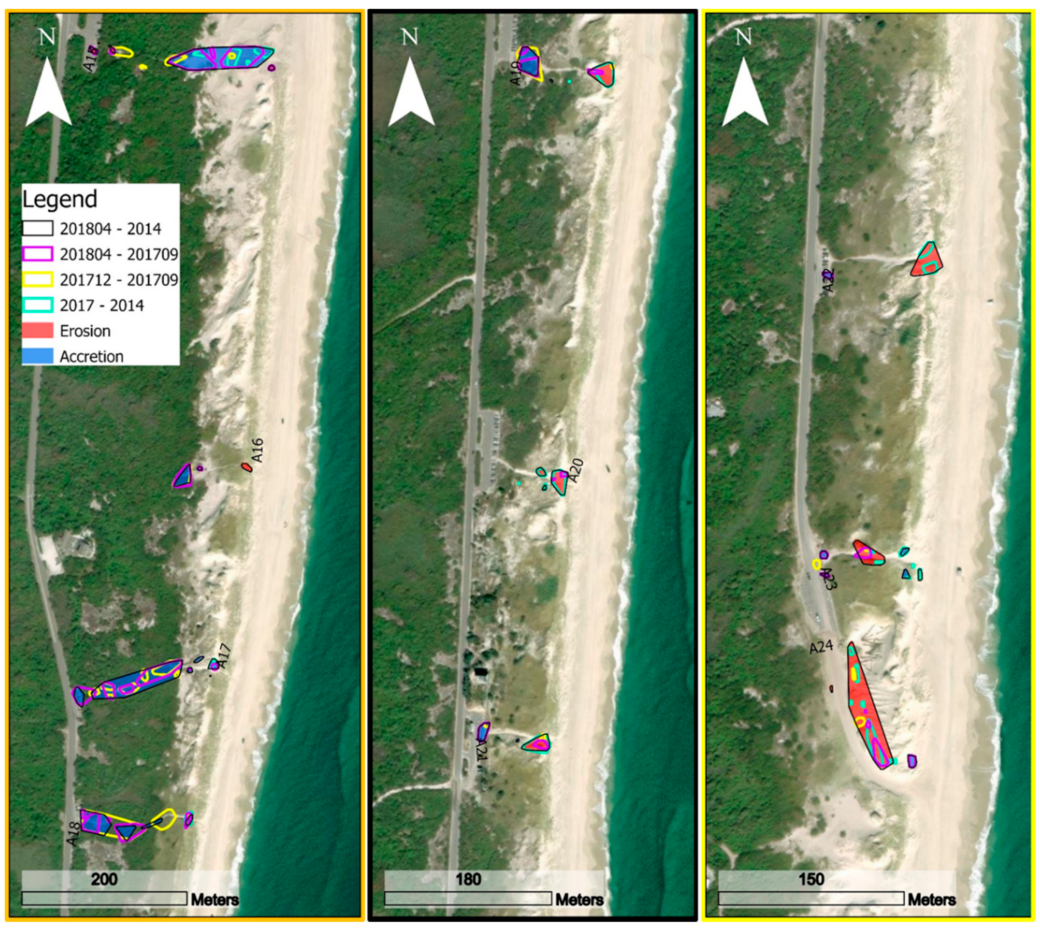

Figure 8. Beach access path impact geometries from 2014 to April 2018. Outlines indicate identified areas of increased elevation change greater than 1 standard deviation of the average elevation change for the difference surface. Red and blue shading indicates categorical elevation change type for whole study period of April 2018-2014. The left map (orange outline) is the northern most section, the center map (black outline) is the central access paths, and the right map (yellow outline) is the most southern access paths.

Paths' impact areas varied in their geometries based on whether erosion or accretion had occurred, but not consistently across time. Only in mesoscale survey period three (De- 
cember 2017 to April 2018) was there a difference in impact geometries between erosional and accretional polygons; specifically, impact area geometries were larger for instances of accretion than erosion in all metrics except orientation: length $\left(\bar{x}_{A}=68.7 \pm 10.3 \mathrm{~m}\right.$, $\left.\bar{x}_{E}=39.6 \pm 13.8 \mathrm{~m}, \mathrm{Z}=2.47, p=0.014\right)$, perimeter $\left(\bar{x}_{A}=171 \pm 24.3 \mathrm{~m}, \bar{x}_{E}=98.6 \pm 31.6 \mathrm{~m}\right.$, $\mathrm{Z}=2.45, p=0.014)$, and surface area $\left(\bar{x}_{A}=2342 \pm 597 \mathrm{~m}^{2}, \bar{x}_{E}=1156 \pm 801 \mathrm{~m}^{2}, \mathrm{Z}=2.25\right.$, $p=0.024)$. Elevation change category did not impact path geometries mesoscale survey periods, one, two, or four.

\section{Discussion}

The greatest elevation changes were associated with unvegetated blowout microhabitats in the event-based microscale collections. Supporting this, $\Delta z$ was unrelated to time between collections and the greatest single pin $\Delta z, 106.7 \mathrm{~cm}$ (Table 4), was in an event-based collection in a blowout, specifically associated with Hurricane Joaquin and a nor'easter event (mid-latitude extratropical cyclone) in fall $2015[13,14]$. The unvegetated $\Delta z$ values observed fit within the range of previously reported values for this microhabitat $[12,13,38,51]$. However, it is important to note that individual blowouts support heterogeneous abiotic conditions translating to heterogeneous transport potentials within them $[42,43,46,65,66]$. As a result, the installation of multiple pins within a blowout would be expected to yield different $\Delta z^{\prime}$ s, as exemplified from the transitional pins typically having lower $\Delta z$ than the unvegetated pins. The unvegetated pin results match those of Harris who observed, over a year, elevation changes in three blowouts ranging from 1-107 cm [45]. In the three-year install, the mean net change in unvegetated pin elevation $(6.2 \pm 10.4 \mathrm{~cm})$ compared to its range each collection (Table 4) suggests that elevation changes are likely ephemeral until or unless vegetation comes to recolonize and stabilize these microhabitats. This may be why blowouts, which are considered ephemeral features themselves, present at the study site in the 1990s may still be present today, 30+ years later [29,46,49].

Microscale measurements support vegetation as stabilizing and retaining aeolian accrued grains. In all collection types (seasonal, event, and monthly), transitional and unvegetated $\Delta z$ were largely equivalent, but one or both were larger than vegetated $\Delta z$ (Figure 4); despite this, the vegetated pins had the greatest net change (Figure 5) and in the seasonal and monthly collections, when both erosion and accretion occurred more concomitantly, vegetated pins were consistently associated with greater instances of accretion than erosion than would be expected by chance, whereas the opposite was true for the other pin types. Differences in vegetation density have been suggested as being a driver of topographic heterogeneity in foredune systems for over four decades [3,24,42,67-69]. However, there exist very few robust examples of topographic heterogeneity being directly attributable to biological factors in situ [34,37,38,70-72] relative to the wide breadth of research on how physical drivers impact transport and alter topography in these systems [57,73-75]. The data presented in this work is robust in both the temporal collection span and frequency and is consistent across analyses, such that we can be confident they are ecologically relevant and persistent [76]. It is important to note a lack of near-surface wind velocity measurements when discussing sediment transport drivers for the statistical findings. Wind velocities for used here to give an understanding of the overall mesoscale winds during seasonal, monthly, and event elevation pin collections. Nevertheless, these data (Table 4) can be a useful source of insight for modelers seeking to incorporate vegetative effects in ecogeomorphic simulation models towards better resource management and conservation efforts over varying spatiotemporal scales [5,56,57,73,77].

Beach access paths impacted localized elevation change and contributed to increased dynamism along path extents relative to vegetated dune areas [78,79]. This level of dynamism in $\Delta z$ was only matched at the dune crest itself and in blowouts (Figure 8) supporting the view that these areas as some of the most unstable and dynamic within the dune habitat, which in turn support the lowest plant species diversity and density [42,80,81]. The impact of access paths on dune systems' ecology and geomorphology are both poorly understood and studied, but are likely self-reinforcing and will remain unvegetated pro- 
vided they remain in use with both trampling and heightened abiotic forcings limiting seedling establishment and colonization $[11,81-83]$ The largely linear unvegetated paths, here, provided longer fetch lengths when aligned with prevailing winds, thus enabling sediment movement inland from the foredune to the maritime forest and beyond $[84,85]$. This suggests that management efforts to alter or construct paths that purposefully include turns, especially out of phase with onshore winds (i.e., easterly at this site), could reduce the funneling of aeolian processes occurring during events and the subsequent migration of sand inland [86].

Comparisons of the two collection methods ultimately shed light on the pros and cons associated with each regarding what can and cannot be gleaned. These differences primarily stem from scale, microscale versus mesoscale, relative to the hypotheses in question [87]. Both metrics are snapshots capturing the state space of a dynamic system [88-90]. However, the remote sensing approach operates at the habitat or ecosystem levels, for both beaches and dunes, and appears better suited to explore geomorphological processes acting at both larger spatial and temporal scales [53,73]. Conversely, field pins appear better suited for exploring biological or ecological processes acting on smaller spatial and temporal scales that are less clearly defined in this and other coastal ecogeomorphic systems $[57,91]$. When geological and biological processes are inextricably linked [9,92], the concomitant collection of both data types may yield more insight than the collection of one versus the other; this line of thinking has allowed other researchers in beach-dune habitats to test biological hypotheses that would previously have been difficult to explore without the use of both remote and field techniques $[37,38,69,93]$.

The concomitant collection of both remote and field data can ultimately contextualize biological data to aid researchers in better understanding an observed or lack of observed pattern. For example, field collections of transect-level biological data may reveal no clear vegetation patterns where they might have been expected. However, zooming out with broader habitat-level topographic data might reveal that the system is in a state of recovery and self-reorganization towards a more stable state, wherein biological patterns may then begin to emerge and be observable [94-96]. The timing of the biological data collection may thus be off. As another example, Charbonneau et al. [38] did not observe the expected differences in the elevation of foredunes dominated by different species surrounding a native and invasive plant [97]. Conversely, Hacker et al. [70] and Goldstein and Moore [98] did observe species-specific topographic variation relative to ecogeomorphic feedbacks. This does not denote a lack of agreement within the system Charbonneau et al. studied; rather it is more likely that the relationships were undetectable when the data were collected because they had not been physically manifested yet, given the incongruent timescales on which biological and geomorphological feedbacks act ecogeomorphologically $[9,88,92,99]$. Event type, interval, and intensity for sites compound this sampling issue and must be considered when collecting and analyzing datasets $[13,14]$.

Biological data collection can also contextualize geomorphic data towards understanding an observed or lack of observed pattern. Topographic data have proven very useful for evaluating the volumetric change of beach-dune systems pre-and post-storm when it may be most apparent [11-14,38]. Here, UAS surveying revealed broader landscape changes (Section 3.1) such as the system being accretional. However, collection frequency and vertical uncertainty were not precise enough to reflect the changes observed at microscale locations, overestimating $\Delta z$ and not accurately predicting $\Delta z$ as erosional or accretional (51-71\% accuracy), thereby obscuring the vegetation-stabilizing effects apparent in all microscale collection timeframes; the high variability around the means between collections (Table 6) necessitates more rather than less data, regardless of data type (field or remote), to evaluate these ecogeomorphic feedbacks and suggests that changes in total elevation may only be visible after a critical period wherein sufficient events have occurred. In repeating this study, using additional ground control points within the survey area and the same UAS system, could have better controlled vertical uncertainty $[14,53,100]$. Increasing flight frequency can be a real challenge, given the need for appropriate weather 
and the associated costs (e.g., time, software, hardware, and data storage, processing, and extraction) relative to the benefits; this is especially true considering field measurements can be comparatively cheap, (e.g., physical effort, time, and data analyzation) $[14,101,102]$. To collect remote data more frequently, one may need alternative methods than those presented here to reduce the costs associated with each survey, re-evaluate the hypothesis being posed in light of the data at hand, or foster interdisciplinary collaborations with the concomitant collection of supporting data.

\section{Conclusions}

Both the micro-and mesoscale metrics highlighted cause-and-effect relationships surrounding a beach-dune system's topographic change, with both the identifying features of heightened dynamism for future monitoring and management efforts. Beach access paths, which funnel aeolian processes, should be counted among some of the most dynamic features in a dune habitat; mesoscale UAS topographic surfaces were necessary to quantify this, as well as habitat-level state changes such as overall beach-dune volumetric and geomorphological change. Plants' presence can limit this dynamism as they played a stabilizing role in the foredune, reducing sediment movement and capturing and eroding less in each accretional and erosional instance, respectively, than unvegetated and partially vegetated transition microhabitats. However, they better retained those grains, ultimately yielding the greatest net change in elevation over the two-year install of all pins, whereas erosion and accretion instances in the other microhabitats were largely ephemeral. Greater precision, accuracy, and data collection frequency of UAS surveys would be needed to adequately explore these plant-related ecogeomorphic feedbacks than was possible with mesoscale data. The cause-and-effect relationships gleaned from each data type and therein what is captured and missed, highlights the different spatial and temporal scales on which biological and geomorphological processes act at in beach-dune systems. Bridging disciplines and data types may ultimately give researchers more power to tease apart complex interconnected ecogeomorphic relationships that structure dynamic beach-dune systems. These data, regardless of type and scale, are baseline snapshots that can ultimately help managers and practitioners to better understand where and how to target vulnerable areas to reduce growing coastal instability.

Supplementary Materials: The following are available online at https: / www.mdpi.com/article / 10.3390/rs13214488/s1. Supplementary 1: Field Pin Types. Supplementary 2: Beach and Dune Automated Feature Extraction. Supplementary 3: Beach Access Path Impacts Tool. Supplementary 4: Grain Size Distributions and Analyses. Supplementary 5: Meteorological Data and Associated Wind Roses.

Author Contributions: Conceptualization, methodology, formal analysis, investigation, resources, data curation, writing — original draft preparation, writing - review and editing, visualization, project administration, funding acquisition, B.R.C. and S.M.D. All authors have read and agreed to the published version of the manuscript.

Funding: This research was conducted with support under contract FA9550-C-0028 and awarded by the Department of Defense, Air Force Office of Scientific Research, National Defense Science and Engineering Graduate (NDSEG) Fellowship, 32 CFR 168a. Additional funds for UAS fieldwork were provided by Delaware Sea Grant Project NOAA SG1011 R/ECO-6 and Virginia Sea Grant Project R/71858. Funding for publication costs provided by the U.S. Naval Research Laboratory, Stennis Space Center, Ocean Sciences Division.

Data Availability Statement: The data presented in this study are available on request from the corresponding author.

Acknowledgments: We thank Brenda Casper for her support while collecting these data, and Art Trembanis and the UD Robotics Discovery Labs for supporting this inter-university collaboration. Many thanks to Hunter Tipton and Peter Barron for their superb UAS fieldwork support. We thank the Office of the New Jersey State Climatologist Rutgers Climate Lab's Mathieu Gerbush and David Robinson for sharing their climate data. We also thank James Eberwine of NOAA NWS and James 
Taggart of Atlantic Cape Community College for connecting us with the Rutgers Climate Lab. We thank Bella Yedman for her assistance in collecting, drying, and sorting the sediment cores.

Conflicts of Interest: The authors declare no conflict of interest. The funders had no role in the design of the study, in the collection, analyses, and interpretation of data, or in the writing of or decision to publish the results of the manuscript.

\section{References}

1. IPCC (Intergovernmental Panel on Climate Change). Climate Change 2014: Synthesis Report. Core Writing Team. 2014, pp. 1-151. Available online: https://www.ipcc.ch/site/assets/uploads/2018/05/SYR_AR5_FINAL_full_wcover.pdf (accessed on 5 November 2021).

2. Arneth, A.; Barbosa, H.; Benton, T.; Calvin, K.; Calvo, E.; Connors, S.; Cowie, A.; Davin, E.; Denton, F.; van Diemen, R.; et al. Summary for Policy Makers. Intergovernmental Panel on Climate Change (IPCC). 2019. Available online: https://www.ipcc.ch/ site/assets/uploads/sites/4/2019/12/02_Summary-for-Policymakers_SPM.pdf (accessed on 5 November 2021).

3. Hesp, P. The Formation of Sand Beach Ridges and Foredunes. Spat. Accuracy 1984, 15, $289-291$.

4. Davenport, J.; Davenport, J.L. The Impact of Tourism and Personal Leisure Transport on Coastal Environments: A Review. Estuar. Coast. Shelf Sci. 2006, 67, 280-292. [CrossRef]

5. Elko, N.; Brodie, K.; Stockdon, H.; Nordstrom, K. Dune Management Challenges on Developed Coasts. Shore Beach 2016, 84, 15-28.

6. Hauer, M.E.; Evans, J.M.; Mishra, D.R. Millions Projected to Be at Risk from Sea-Level Rise in the Continental United States. Nat. Clim. Chang. 2016, 6, 691-695. [CrossRef]

7. Biel, R.G.; Hacker, S.D.; Ruggiero, P.; Cohn, N.; Seabloom, E.W. Coastal Protection and Conservation on Sandy Beaches and Dunes: Context-Dependent Tradeoffs in Ecosystem Service Supply. Ecosphere 2017, 8, e01791. [CrossRef]

8. Sallenger, J.A.H. Storm Impact Scale for Barrier Islands. J. Coast Res. 2000, 16, 890-895. [CrossRef]

9. Stallins, J.A.; Parker, A.J. The Influence of Complex Systems Interactions on Barrier Island Dune Vegetation Pattern and Process. Ann. Assoc. Am. Geogr. 2003, 93, 13-29. [CrossRef]

10. Doran, K.S.; Stockdon, H.F.; Sopkin, K.L.; Thompson, D.M.; Plant, N.G. National Assessment of Hurricane-Induced Coastal Erosion Hazards: Mid-Atlantic Coast. In U.S. Geological Survey Open-File Report; U.S. Geological Survey: Reston, VA, USA, 2013; 28p.

11. Barone, D.A.; McKenna, K.K.; Farrell, S.C. Hurricane Sandy: Beach-Dune Performance at New Jersey Beach Profile Network Sites. Shore Beach 2014, 82, 13-23.

12. Houser, C.; Wernette, P.; Rentschlar, E.; Jones, H.; Hammond, B.; Trimble, S. Post-Storm Beach and Dune Recovery: Implications for Barrier Island Resilience. Geomorphology 2015, 234, 54-63. [CrossRef]

13. Dohner, S.M.; Trembanis, A.C.; Miller, D.C. A Tale of Three Storms: Morphologic Response of Broadkill Beach, Delaware, Following Superstorm Sandy, Hurricane Joaquin, and Winter Storm Jonas. Shore Beach 2016, 84, 3.

14. Dohner, S.M.; Pilegard, T.C.; Trembanis, A.C. Coupling Traditional and Emergent Technologies for Improved Coastal Zone Mapping. Estuaries Coasts 2020, 1-23. [CrossRef]

15. Delgado-Fernandez, I.; Davidson-Arnott, R. Meso-Scale Aeolian Sediment Input to Coastal Dunes: The Nature of Aeolian Transport Events. Geomorphology 2011, 126, 217-232. [CrossRef]

16. Jackson, N.L.; Nordstrom, K.F. Aeolian Sediment Transport on a Recovering Storm-Eroded Foredune with Sand Fences. Earth Surf. Process. Landf. 2018, 43, 1310-1320. [CrossRef]

17. Nordstrom, K.F.; Jackson, N.L. Offshore Aeolian Sediment Transport across a Human-Modified Foredune. Earth Surf. Proc. Land. 2018, 43, 195-201. [CrossRef]

18. Gabarrou, S.; Cozannet, G.L.; Parteli, E.J.R.; Pedreros, R.; Guerber, E.; Millescamps, B.; Mallet, C.; Oliveros, C. Modelling the Retreat of a Coastal Dune under Changing Winds. J. Coast. Res. 2018, 85, 166-170. [CrossRef]

19. Houser, C.; Hapke, C.; Hamilton, S. Controls on Coastal Dune Morphology, Shoreline Erosion and Barrier Island Response to Extreme Storms. Geomorphology 2008, 100, 223-240. [CrossRef]

20. Houser, C.; Mathew, S. Alongshore Variation in Foredune Height in Response to Transport Potential and Sediment Supply: South Padre Island, Texas. Geomorphology 2011, 125, 62-72. [CrossRef]

21. Keijsers, J.G.S.; Poortinga, A.; Riksen, M.J.P.M.; Maroulis, J. Spatio-Temporal Variability in Accretion and Erosion of Coastal Foredunes in the Netherlands: Regional Climate and Local Topography. PLoS ONE 2014, 9, e91115. [CrossRef]

22. Keijsers, J.G.S.; Groot, A.V.D.; Riksen, M.J.P.M. Modeling the Biogeomorphic Evolution of Coastal Dunes in Response to Climate Change. J. Geophys. Res. Earth Surf. 2016, 121, 1161-1181. [CrossRef]

23. Bryant, D.B.; Bryant, M.A.; Sharp, J.A.; Bell, G.L.; Moore, C. The Response of Vegetated Dunes to Wave Attack. Coast. Eng. 2019, 152, 103506. [CrossRef]

24. Goldsmith, V.; Rosen, P.; Gertner, Y. Eolian transport measurements, winds, and comparison with theoretical transport on Israeli coastal dunes. In Coastal Dunes: Processes and Morphology; Nordstrom, K., Psuty, N., Carter, R., Eds.; Wiley \& Sons, Ltd.: London, UK, 1991; Volume 5, pp. 79-101.

25. Jackson, N.L.; Nordstrom, K.F. Aeolian Transport of Sediment on a Beach during and after Rainfall, Wildwood, NJ, USA. Geomorphology 1998, 22, 151-157. [CrossRef] 
26. Delgado-Fernandez, I.; Davidson-Arnott, R.; Bauer, B.O.; Walker, I.J.; Ollerhead, J.; Rhew, H. Assessing Aeolian Beach-Surface Dynamics Using a Remote Sensing Approach. Earth Surf. Process. Landf. 2012, 37, 1651-1660. [CrossRef]

27. Nordstrom, K.F.; Jackson, N.L. The Role of Wind Direction in Eolian Transport on a Narrow Sandy Beach. Earth Surf. Proc. Land. 1993, 18, 675-685. [CrossRef]

28. Arens, S.M. Rates of Aeolian Transport on a Beach in a Temperate Humid Climate. Geomorphology 1996, 17, 3-18. [CrossRef]

29. Gares, P.A.; Nordstrom, K.F. A Cyclic Model of Foredune Blowout Evolution for a Leeward Coast: Island Beach, New Jersey. Ann. Assoc. Am. Geogr. 1995, 85, 1-20. [CrossRef]

30. Bauer, B.O.; Davidson-Arnott, R.G.D.; Walker, I.J.; Hesp, P.A.; Ollerhead, J. Wind Direction and Complex Sediment Transport Response across a Beach-Dune System. Earth Surf. Proc. Land. 2012, 37, 1661-1677. [CrossRef]

31. Bauer, B.O.; Hesp, P.A.; Walker, I.J.; Davidson-Arnott, R.G.D. Sediment Transport (Dis)Continuity across a Beach-Dune Profile during an Offshore Wind Event. Geomorphology 2015, 245, 135-148. [CrossRef]

32. Moreno-Casasola, P. Sand Movement as a Factor in the Distribution of Plant Communities in a Coastal Dune System. Vegetatio 1986, 65, 67-76. [CrossRef]

33. Olson, J.S. Lake Michigan Dune Development 1. Wind-Velocity Profiles. J. Geol. 1958, 66, 254-263. [CrossRef]

34. Zarnetske, P.L.; Hacker, S.D.; Seabloom, E.W.; Ruggiero, P.; Killian, J.R.; Maddux, T.B.; Cox, D. Biophysical Feedback Mediates Effects of Invasive Grasses on Coastal Dune Shape. Ecology 2012, 93, 1439-1450. [CrossRef] [PubMed]

35. Keijsers, J.G.S.; Groot, A.V.D.; Riksen, M.J.P.M. Vegetation and Sedimentation on Coastal Foredunes. Geomorphology 2015, 228, 723-734. [CrossRef]

36. Ashkenazy, Y.; Shilo, E. Sand Dune Albedo Feedback. Geosciences 2018, 8, 82. [CrossRef]

37. Charbonneau, B.R.; Dohner, S.M.; Wnek, J.P.; Barber, D.; Zarnetske, P.L.; Casper, B.B. Vegetation Effects on Coastal Foredune Initiation: Wind Tunnel Experiments and Field Validation for Three Dune-Building Plants. Geomorphology 2021, $378,107594$. [CrossRef]

38. Charbonneau, B.R.; Wootton, L.S.; Wnek, J.P.; Langley, J.A.; Posner, M.A. A Species Effect on Storm Erosion: Invasive Sedge Stabilized Dunes More than Native Grass during Hurricane Sandy. J. Appl. Ecol. 2017, 54, 1385-1394. [CrossRef]

39. da Silva, G.M.; Hesp, P.; Peixoto, J.; Dillenburg, S.R. Foredune Vegetation Patterns and Alongshore Environmental Gradients: Moçambique Beach, Santa Catarina Island, Brazil. Earth Surf. Process. Landf. 2008, 33, 1557-1573. [CrossRef]

40. Hesp, P.A.; Dong, Y.; Cheng, H.; Booth, J.L. Wind Flow and Sedimentation in Artificial Vegetation: Field and Wind Tunnel Experiments. Geomorphology 2019, 337, 165-182. [CrossRef]

41. Arens, S.M. Patterns of Sand Transport on Vegetated Foredunes. Geomorphology 1996, 17, 339-350. [CrossRef]

42. Hesp, P. Foredunes and Blowouts: Initiation, Geomorphology and Dynamics. Geomorphology 2002, 48, 245-268. [CrossRef]

43. Sun, Y.; Hasi, E.; Liu, M.; Du, H.; Guan, C.; Tao, B. Airflow and Sediment Movement within an Inland Blowout in Hulun Buir Sandy Grassland, Inner Mongolia, China. Aeolian Res. 2016, 22, 13-22. [CrossRef]

44. Smith, A.; Gares, P.A.; Wasklewicz, T.; Hesp, P.A.; Walker, I.J. Three Years of Morphologic Changes at a Bowl Blowout, Cape Cod, USA. Geomorphology 2017, 295, 452-466. [CrossRef]

45. Harris, C. Wind Speed and Sand Movement in a Coastal Dune Environment. Area 1974, 6, 243-249.

46. Gares, P.A. Topographic Changes Associated with Coastal Dune Blowouts at Island Beach State Park, New Jersey. Earth Surf. Process. Landf. 1992, 17, 589-604. [CrossRef]

47. Cooper, W.S. Coastal Sand Dunes of Oregon and Washington. Geol. Soc. Am. Mem. 1958, 72, 170. [CrossRef]

48. Frosini, S.; Lardicci, C.; Balestri, E. Global Change and Response of Coastal Dune Plants to the Combined Effects of Increased Sand Accretion (Burial) and Nutrient Availability. PLoS ONE 2012, 7, e47561. [CrossRef] [PubMed]

49. Charbonneau, B. From The Sand They Rise: Post-Storm Foredune Plant Recolonization and Its Biogeomorphic Implications. Ph.D. Thesis, University of Pennsylvania, Philadelphia, PA, USA, 2019.

50. Lichter, J. Colonization Constraints during Primary Succession on Coastal Lake Michigan Sand Dunes. J. Ecol. 2000, 88, 825-839. [CrossRef]

51. Johnson, E.A.; Miyanishi, K. Coastal dune succession and the reality of dune processes. In Plant Disturbance Ecology; Plant Disturbance Ecology; Elsevier: London, UK, 2007; pp. 249-282.

52. Maun, M.A.; Lapierre, J. Effects of Burial by Sand on Seed Germination and Seedling Emergence of Four Dune Species. Am. J. Bot. 1986, 73, 450-455. [CrossRef]

53. Moore, L.J. Shoreline Mapping Techniques. J. Coast. Res. 2000, 16, 111-124. [CrossRef]

54. Hamylton, S.M. Spatial Analysis of Coastal Environments; Cambridge University Press: Cambridge, UK, 2017.

55. Harley, M.D.; Turner, I.L.; Kinsela, M.A.; Middleton, J.H.; Mumford, P.J.; Splinter, K.D.; Phillips, M.S.; Simmons, J.A.; Hanslow, D.J.; Short, A.D. Extreme Coastal Erosion Enhanced by Anomalous Extratropical Storm Wave Direction. Sci. Rep. 2017, 7, 6033. [CrossRef] [PubMed]

56. Elko, N.; Dietrich, C.; Cialone, M.; Stockdon, H.; Bilskie, M.W.; Boyd, B.; Charbonneau, B.R.; Cox, D.; Dresback, K.; Elgar, S.; et al. Advancing the Understanding of Storm Processes and Impacts. Shore Beach 2019, 87, 37-51.

57. Jackson, N.L.; Nordstrom, K.F. Trends in Research on Beaches and Dunes on Sandy Shores, 1969-2019. Geomorphology 2020, 366, 106737. [CrossRef]

58. Vinent, O.D.; Moore, L.J. Barrier Island Bistability Induced by Biophysical Interactions. Nat. Clim. Chang. 2015, 5, 158-162. [CrossRef] 
59. Spore, N.; Brodie, K.; Swann, C. Automated Feature Extraction of Foredune Morphology from Terrestrial Lidar Data. AGU Fall Meeting Abstracts. 2014, p. EP31B-3558. Available online: https://ui.adsabs.harvard.edu/abs/2014AGUFMEP31B3558S/abstract (accessed on 5 November 2021).

60. Ruiz-Martínez, G.; Rivillas-Ospina, G.; Mariño-Tapia, I.; Posada-Vanegas, G. SANDY: A Matlab Tool to Estimate the Sediment Size Distribution from a Sieve Analysis. Comput. Geosci. 2016, 92, 104-116. [CrossRef]

61. Pereira, D. Wind Rose. MATLAB Central File Exchang. 2021. Available online: https://www.mathworks.com/matlabcentral/ fileexchange/47248-wind-rose (accessed on 10 September 2021).

62. MATLAB. MATLAB and Statistics and Machine Learning Toolbox Release 2018a; MATLAB: Natick, MA, USA, 2018.

63. Zingg, A. Wind Tunnel Studies of The Movement of Sedimentary Material. In Proceedings of the 5th Hydraulics Conference, Iowa City, IA, USA, 9-11 June 1953; Iowa institute of Hydraulic Research: Iowa City, IA, USA; Volume 34, pp. 11-135.

64. Bagnold, R.A. The Physics of Blown Sand and Desert Dunes; William Morrow and Company: New York, NY, USA, 1943.

65. Hesp, P.; Hyde, R. Flow Dynamics and Geomorphology of a Trough Blowout. Sedimentology 1996, 43, 505-525. [CrossRef]

66. Hesp, P.A. Flow Dynamics in a Trough Blowout. Bound.-Layer Meteorol. 1996, 77, 305-330. [CrossRef]

67. Hesp, P. Morphodynamics of Incipient Foredunes in New South Wales, Australia. In Eolian Sediments and Processes; Elsevier: Amsterdam, The Netherlands, 1983; Volume 38, pp. 325-342. ISBN 9780444422330.

68. Hesp, P.A. Foredune formation in SE Australia. In Coastal Geomorphology in Australia; Thom, B.G., Ed.; Academic Press: Cambridge, MA, USA, 1984; pp. 60-97.

69. Jagschitz, J.A.; Wakefield, R.C. How to Build and Save Beaches and Dunes; College of Resource Development, University of Rhode Island: Kingston, RI, USA, 1971.

70. Hacker, S.D.; Jay, K.R.; Cohn, N.; Goldstein, E.B.; Hovenga, P.A.; Itzkin, M.; Moore, L.J.; Mostow, R.S.; Mullins, E.V.; Ruggiero, P. Species-Specific Functional Morphology of Four US Atlantic Coast Dune Grasses: Biogeographic Implications for Dune Shape and Coastal Protection. Diversity 2019, 11, 82. [CrossRef]

71. Zarnetske, P.L.; Ruggiero, P.; Seabloom, E.W.; Hacker, S.D. Coastal Foredune Evolution: The Relative Influence of Vegetation and Sand Supply in the US Pacific Northwest. J. R. Soc. Interface 2015, 12, 20150017. [CrossRef]

72. Biel, R.G.; Hacker, S.D.; Ruggiero, P. Elucidating Coastal Foredune Ecomorphodynamics in the U.S. Pacific Northwest via Bayesian Networks. J. Geophys. Res. Earth Surf. 2019, 124, 1919-1938. [CrossRef]

73. Walker, I.J.; Davidson-Arnott, R.G.D.; Bauer, B.O.; Hesp, P.A.; Delgado-Fernandez, I.; Ollerhead, J.; Smyth, T.A.G. Scale-Dependent Perspectives on the Geomorphology and Evolution of Beach-Dune Systems. Earth-Sci. Rev. 2017, 171, 220-253. [CrossRef]

74. Česnulevičius, A.; Bautrènas, A.; Bevainis, L.; Ovodas, D.; Papšys, K. Applicability of Unmanned Aerial Vehicles in Research on Aeolian Processes. Pure Appl. Geophys. 2018, 175, 3179-3191. [CrossRef]

75. Solazzo, D.; Sankey, J.; Sankey, T. Mapping and Measuring Aeolian Sand Dunes with Photogrammetry and LiDAR from Unmanned Aerial Vehicles (UAV) and Multispectral Satellite Imagery on the Paria Plateau, AZ, USA. Geomorphology 2018, 319, 174-185. [CrossRef]

76. Baird, D.J.; Brown, S.S.; Lagadic, L.; Liess, M.; Maltby, L.; Moreira-Santos, M.; Schulz, R.; Scott, G.I. In Situ-Based Effects Measures: Determining the Ecological Relevance of Measured Responses. Integr. Environ. Assess. Manag. 2007, 3, 259-267. [CrossRef] [PubMed]

77. Feagin, R.A.; Figlus, J.; Zinnert, J.C.; Sigren, J.; Martínez, M.L.; Silva, R.; Smith, W.K.; Cox, D.; Young, D.R.; Carter, G. Going with the Flow or against the Grain? The Promise of Vegetation for Protecting Beaches, Dunes, and Barrier Islands from Erosion. Front. Ecol. Environ. 2015, 13, 203-210. [CrossRef]

78. Laporte-Fauret, Q.; Castelle, B.; Michalet, R.; Marieu, V.; Bujan, S.; Rosebery, D. Morphological and Ecological Responses of a Managed Coastal Sand Dune to Experimental Notches. Sci. Total Environ. 2021, 782, 146813. [CrossRef]

79. Castelle, B.; Laporte-Fauret, Q.; Marieu, V.; Michalet, R.; Rosebery, D.; Bujan, S.; Lubac, B.; Bernard, J.-B.; Valance, A.; Dupont, P.; et al. Nature-Based Solution along High-Energy Eroding Sandy Coasts: Preliminary Tests on the Reinstatement of Natural Dynamics in Reprofiled Coastal Dunes. Water 2018, 11, 2518. [CrossRef]

80. Hesp, P.A.; Martínez, M.L. Plant Disturbance Ecology. Disturbance Processes and Dynamics in Coastal Dunes; Elsevier: Amsterdam, The Netherlands, 2007; ISBN 9780120887781.

81. Gallego-Fernández, J.B.; Martínez, M.L. Environmental Filtering and Plant Functional Types on Mexican Foredunes along the Gulf of Mexico. Écoscience 2015, 18, 52-62. [CrossRef]

82. Purvis, K.G.; Gramling, J.M.; Murren, C.J. Assessment of Beach Access Paths on Dune Vegetation: Diversity, Abundance, and Cover. J. Coast. Res. 2015, 315, 1222-1228. [CrossRef]

83. Prisco, I.; Acosta, A.T.R.; Stanisci, A. A Bridge between Tourism and Nature Conservation: Boardwalks Effects on Coastal Dune Vegetation. J. Coast. Conserv. 2021, 25, 14. [CrossRef]

84. Riksen, M.J.P.M.; Goossens, D.; Huiskes, H.P.J.; Krol, J.; Slim, P.A. Constructing Notches in Foredunes: Effect on Sediment Dynamics in the Dune Hinterland. Geomorphology 2016, 253, 340-352. [CrossRef]

85. Ruessink, B.G.; Arens, S.M.; Kuipers, M.; Donker, J.J.A. Coastal Dune Dynamics in Response to Excavated Foredune Notches. Aeolian Res. 2018, 31, 3-17. [CrossRef]

86. Pye, K.; Blott, S. Dune Rejuvenation Trials Overview Report. Natural Resources Wales Evidence Report Series Report No: 296; Kenneth Py Associates Ltd.: Reading, UK, 2016.

87. Stallins, J.A. Scale, Causality, and the New Organism-Environment Interaction. Geoforum 2012, 43, 427-441. [CrossRef] 
88. Zinnert, J.C.; Stallins, J.A.; Brantley, S.T.; Young, D.R. Crossing Scales: The Complexity of Barrier-Island Processes for Predicting Future Change. BioScience 2017, 67, 39-52. [CrossRef]

89. Stallins, J.A.; Corenblit, D. Interdependence of Geomorphic and Ecologic Resilience Properties in a Geographic Context. Geomorphology 2018, 305, 76-93. [CrossRef]

90. Monge, J.A.; Stallins, J.A. Properties of Dune Topographic State Space for Six Barrier Islands of the U.S. Southeastern Atlantic Coast. Phys. Geogr. 2016, 37, 452-475. [CrossRef]

91. Hanley, M.E.; Bouma, T.J.; Mossman, H.L. The Gathering Storm: Optimizing Management of Coastal Ecosystems in the Face of a Climate-Driven Threat. Ann. Bot. 2020, 125, 197-212. [CrossRef] [PubMed]

92. Stallins, J.A. Geomorphology and Ecology: Unifying Themes for Complex Systems in Biogeomorphology. Geomorphology 2006, 77, 207-216. [CrossRef]

93. Kim, D.; Yu, K.B.; Park, S.J. Identification and Visualization of Complex Spatial Pattern of Coastal Dune Soil Properties Using GIS-Based Terrain Analysis and Geostatistics. J. Coast. Res. 2008, 4, 50-60. [CrossRef]

94. Snyder, R.A.; Boss, C.L. Recovery and Stability in Barrier Island Plant Communities. J. Coast. Res. 2002, 18, 530-536. [CrossRef]

95. Cheplick, G.P. Changes in Plant Abundance on a Coastal Beach Following Two Major Storm Surges 1. J. Torrey Bot. Soc. 2016, 143, 180-191. [CrossRef]

96. Wolner, C.W.V.; Moore, L.J.; Young, D.R.; Brantley, S.T.; Bissett, S.N.; McBride, R.A. Ecomorphodynamic Feedbacks and Barrier Island Response to Disturbance: Insights from the Virginia Barrier Islands, Mid-Atlantic Bight, USA. Geomorphology 2013, 199, 115-128. [CrossRef]

97. Wootton, L.S.; Halsey, S.D.; Bevaart, K.; McGough, A.; Ondreicka, J.; Patel, P. When Invasive Species Have Benefits as Well as Costs: Managing Carex Kobomugi (Asiatic Sand Sedge) in New Jersey's Coastal Dunes. Biol. Invasions 2005, 7, 1017-1027. [CrossRef]

98. Goldstein, E.B.; Moore, L.J.; Vinent, O.D. Lateral Vegetation Growth Rates Exert Control on Coastal Foredune "Hummockiness" and Coalescing Time. Earth Surf. Dyn. 2017, 5, 417-427. [CrossRef]

99. Murray, A.B.; Knaapen, M.A.F.; Tal, M.; Kirwan, M.L. Biomorphodynamics: Physical-biological Feedbacks That Shape Landscapes. Water Resour. Res. 2008, 44, W11301. [CrossRef]

100. Rogers, S.; Manning, I.; Livingstone, W. Comparing the Spatial Accuracy of Digital Surface Models from Four Unoccupied Aerial Systems: Photogrammetry Versus LiDAR. Remote Sens. 2020, 12, 2806. [CrossRef]

101. Linchant, J.; Lisein, J.; Semeki, J.; Lejeune, P.; Vermeulen, C. Are Unmanned Aircraft Systems (UASs) the Future of Wildlife Monitoring? A Review of Accomplishments and Challenges. Mammal Rev. 2015, 45, 239-252. [CrossRef]

102. Fitzpatrick, B.P. Unmanned Aerial Systems for Surveying and Mapping: Cost Comparison of UAS Versus Traditional Methods of Data Acquisition. Ph.D. Thesis, University of Southern California, Los Angeles, CA, USA, 2016. 